\title{
Nutrient preservation, analysis precision and quality control of an oceanographic database of inorganic nutrients, dissolved oxygen and chlorophyll $a$ from the NW Mediterranean Sea
}

\author{
MARIONA SEGURA-NOGUERA ${ }^{1,2}$, ANTONIO CRUZADO $^{3}$ and DOLORS BLASCO ${ }^{1}$ \\ ${ }^{1}$ Department of Marine Biology and Oceanography, Institut de Ciències del Mar, CSIC, Barcelona, Catalonia. \\ ${ }^{2}$ Present address: School of Ocean and Earth Science and Technology, Center for Microbial Oceanography: Research and \\ Education, University of Hawaii, Honolulu, Hawaii 96822, USA. E-mail: mariona@ marionasegura.cat \\ ${ }^{3}$ Department of Aquatic Biogeochemistry, Centre d'Estudis Avançats de Blanes, CSIC, Blanes, Catalonia
}

\begin{abstract}
SUMMARY: Oceanographic data from 28 cruises performed in the NW Mediterranean Sea between 1982 and 2003 and data from historical databases, amounting to more than 100000 data points, are used to define the quality control ranges at standard level depths of dissolved inorganic nutrients, dissolved oxygen and chlorophyll $a$. The quality of each of the key variables and the analytical precision are assessed. The results indicate that freezing is a valid preservation method for phosphate, nitrate, silicate and nitrite in samples from the NW Mediterranean Sea, though their relative error increases $(6.3 \%,-1.6 \%,-2.5 \%$ and $-11.4 \%$, respectively). In contrast, freezing nutrient samples on the cruises gathered negatively affected the analytical precision and accuracy of the ammonium analysis. The analysis precision is also estimated using different approximations, the most realistic being the use of replicate samples from the same sampling bottle. Except for phosphate and dissolved oxygen, specific quality control ranges for mixed water columns, usually found in winter, have to be defined, since the surface concentrations are particularly high due to deep water mixing. The quality-controls described in this work are an important and useful tool for validating data and for detecting erroneous or anomalous data obtained in both historical and future works in the NW Mediterranean Sea.
\end{abstract}

Keywords: dissolved inorganic nutrients, dissolved oxygen, chlorophyll $a$, nutrient preservation, analysis precision, quality control, NW Mediterranean Sea.

RESUMEN: CONSERVACIÓN DE NUTRIENTES, PRECISIÓN DE LOS ANÁLISIS Y CONTROL DE CALIDAD DE UNA BASE DE DATOS OCEANOGRÁFICA CON NUTRIENTES INORGÁNICOS, OXÍGENO DISUELTO Y CLOROFILA A DEL MEDITERRÁNEO NOROCCIDENTAL. - Se han utilizado datos oceanográficos de 28 campañas realizadas entre 1982 y 2003 en el Mediterráneo noroccidental, así como de bases de datos históricas, para definir rangos de control de calidad en niveles de profundidad estándares para nutrientes inorgánicos, oxígeno disuelto y clorofila $a$. La calidad de cada una de estas variables clave, así como la precisión analítica, han sido evaluadas. Los resultados indican que la congelación es un método válido para conservar las concentraciones de fosfato, nitrato, silicato y nitrito en muestras procedentes del Mediterráneo noroccidental, aunque el error relativo del análisis incrementa $(6.3 \%,-1.6 \%,-2.5 \%$ y $-11.4 \%$ respectivamente). En cambio, en las campañas recopiladas la congelación de muestras de nutrientes ha afectado negativamente a la precisión y exactitud del análisis de amonio. La precisión de los análisis también ha sido estimada utilizando diferentes aproximaciones, siendo la más realista el uso de réplicas procedentes de la misma botella de muestreo. Excepto para fosfato y oxígeno disuelto, se han definido rangos de control de calidad específicos en condiciones de columnas de agua mezcladas, típicas de invierno, puesto que las concentraciones superficiales resultan particularmente elevadas debido a la mezcla con aguas profundas. Los rangos de control de calidad descritos en el presente trabajo son una herramienta útil e importante para validar datos oceanográficos, para detectar datos erróneos o anómalos, obtenidos en el pasado o futuros trabajos en el Mediterráneo noroccidental.

Palabras clave: nutrientes inorgánicos disueltos, oxígeno disuelto, clorofila $a$, conservación de nutrientes, precisión analítica, control de calidad, Mar Mediterráneo. 


\section{INTRODUCTION}

Oceanographic databases are basic tools for preserving historical observations and for describing and tracking changes in ecosystems. Researchers constructing databases that include decades of oceanographic research should take into account that most probably there are very significant differences in the way the measurements were obtained. Such differences include changes in the analysis instruments, the sampling and the preservation procedures. Therefore, it is necessary to check whether data collected and processed using different methodologies and precisions can be combined. Subsequently, a quality-control (QC) for each variable should be applied in order to obtain a scientifically quality-controlled database. Since nowadays so much research is used to try to determine climate change or anthropogenic impacts, basic information about the analysis precision, limit of detection and other analytical characteristics is critical.

The study of the quality of oceanographic data gathered from different sources has been raised by others, and QC procedures have already been described for the whole oceans (Conkright et al., 1994, 2000). Also, Fichaut et al. (1997) defined ranges of T, S and dissolved oxygen in our study area (region DS2 in MEDATLAS database), often with one single concentration range for the whole water column. However, there is no information about the ranges of concentration for nutrients and chlorophyll $a(\mathrm{chl} a)$ in the MEDATLAS database. In this article, our aim is to establish the ranges of concentration with depth for the main biochemical variables (nutrients, dissolved oxygen and chl $a$ ) in the NW Mediterranean Sea, the most productive area of the Mediterranean Sea. The oceanographic database gathered to accomplish this objective contains data from the almost annual oceanographic cruises performed since 1982 in the Catalan Sea, as well as historical data from MEDATLAS (Medar Group, 2002) and MATER (Mater Group, 2001) databases. The available oceanographic data include dissolved inorganic nutrients (phosphate, nitrate+nitrite (hereafter referred to as nitrate), nitrite, ammonium and silicate), dissolved oxygen and chl $a$, as well as temperature (T) and salinity (S).
The QC described in this work will be an important and useful tool for identifying erroneous or non-representative measurements of oceanographic data obtained in future studies in the NW Mediterranean Sea. Quality controlled data will provide a more accurate climatology of the NW Mediterranean Sea for the description of the distribution of nutrients, dissolved oxygen and chl $a$ (Segura-Noguera et al., submitted) for modeling the dynamics of the system and for studying long-term variations (e.g. seasonality or inter-annual trends, Segura-Noguera et al., in preparation).

\section{MATERIALS AND METHODS}

\section{Data source}

Oceanographic data from 28 cruises performed in the NW Mediterranean Sea between 1982 and 2003, amounting to 1388 stations, were gathered (see Appendix 1 for more characteristics and instrumentation used on the cruises gathered). The information available for each station included date, position, sampling time and maximum depth. Information available for each water sample included depth $(\mathrm{m}), \mathrm{T}\left({ }^{\circ} \mathrm{C}\right), \mathrm{S}$ (practical salinity units), and density as $\sigma-\mathrm{T}\left(\mathrm{kg} \mathrm{m}^{-3}\right)$. Depending on the cruise, data of dissolved inorganic nutrients $(\mu \mathrm{M})$, dissolved oxygen $\left(\mathrm{ml} \mathrm{l}^{-1}\right)$ and chl $a\left(\mu \mathrm{gl}^{-1}\right)$ concentrations, were available.

In order to complement this information and to increase the pool of data for statistical analysis, data from the MEDATLAS (Medar Group, 2002) and MATER (Mater Group, 2001) databases were extracted using as limits for the extraction area the most extreme latitude and longitude of the cruises gathered (from 0 to $4.5^{\circ} \mathrm{W}$ and from 38.7 to $42.4^{\circ} \mathrm{N}$, Fig. 1). MEDATLAS and MATER databases include data earlier than 1982, as indicated in Table 1, where the amount of data for each oceanographic variable is indicated. Among all the collected cruises, only data from the "Mater 95" cruise was included in both databases, and therefore it was checked that this cruise was not duplicated in the final working database. Data from stations with a bottom depth higher than $400 \mathrm{~m}$ (considered as "open sea," according to Medar Group, 2002) are also indicated in Table 1, because they will be used to define

TABLE 1. - Total data and data from open sea stations for each oceanographic variable, obtained from the cruises gathered ("cruises" including "Meso 95") and extracted from MEDATLAS and MATER Databases ("databases"). Open sea refers to stations with a bottom depth higher than $400 \mathrm{~m}$.

\begin{tabular}{|c|c|c|c|c|c|c|c|}
\hline & \multirow[t]{2}{*}{ Range of years } & \multicolumn{3}{|c|}{ Total data from: } & \multicolumn{3}{|c|}{ Open sea data from: } \\
\hline & & Cruises & Databases & TOTAL & Cruises & Databases & TOTAL \\
\hline Phosphate & $1957-2003$ & 8993 & 6466 & 15459 & 6179 & 3087 & 9266 \\
\hline Nitrate & $1979-2003$ & 13971 & 572 & 14543 & 9811 & 387 & 10198 \\
\hline Nitrite & $1976-2003$ & 12984 & 4903 & 17887 & 8954 & 2421 & 11375 \\
\hline Ammonium & $1982-2003$ & 4944 & 481 & 5425 & 3682 & 223 & 3905 \\
\hline Silicate & $1970-2003$ & 14013 & 5857 & 19870 & 9831 & 2844 & 12675 \\
\hline Oxygen & $1910-2000$ & 10247 & 8357 & 18604 & 7455 & 5394 & 12849 \\
\hline Chl $a$ & $1976-2003$ & 7201 & 3530 & 10731 & 5009 & 1446 & 6455 \\
\hline Total & & 72353 & 30166 & 102519 & 50921 & 15802 & 66723 \\
\hline
\end{tabular}


TABLE 2. - Criteria used to define the stratification coefficient of the profiles according to the vertical stratification index at $100 \mathrm{~m}$ depth (VDSI100) calculated.

\begin{tabular}{|c|c|c|c|}
\hline Stratification coefficient & VDSI100 & Most representative season & Months in which this coefficient was found \\
\hline 1 & $\leq 5 ;$ surface $\mathrm{T}<15$ & Winter & November-April \\
\hline 2 & $(5,30]$ & Spring & April-July \\
\hline 3 & $>30 ;$ surface $\mathrm{T}>24$ & Summer & June-September \\
\hline 4 & $(5,30]$ & Autumn & September-December \\
\hline
\end{tabular}

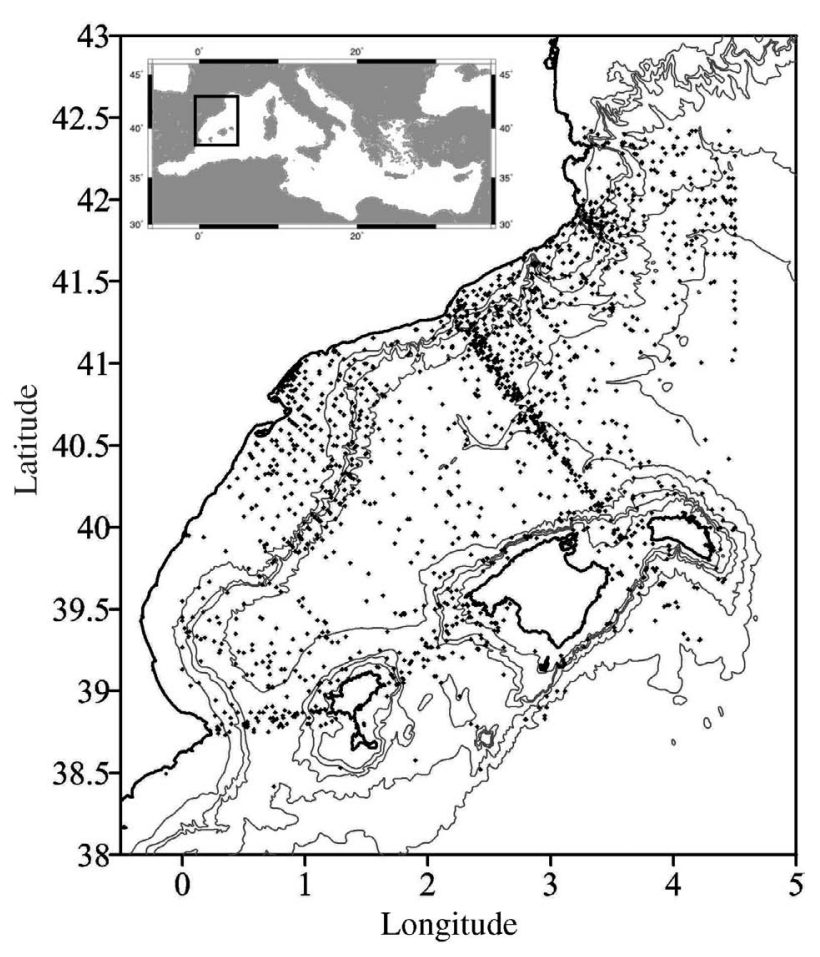

FIG. 1. - Map of the Catalan Sea with the position of the oceanographic stations sampled during the cruises collected for this study. The inlet map shows the position of the Catalan Sea in the Mediterranean Sea.

the QC ranges for the NW Mediterranean Sea, following the procedures described in Conkright et al. (1994, 2000). The map of the NW Catalan Sea with all the stations sampled, including the data extracted from the MEDATLAS and MATER databases, is shown in Figure 1.

The regional limits for $\mathrm{T}$ and $\mathrm{S}$ described by the Medar Group (2002) were used to validate the quality of $\mathrm{T}$ and $\mathrm{S}$ data. As a result, less than $0.2 \%$ and $0.5 \%$ of the data, respectively, was found outside the limits. The most striking feature for these variables was a few low $\mathrm{S}$ values, which could be explained by their position close to the Ebro River Delta.

\section{Analytical precision}

The nutrient analysis precision is reported only for the "Fronts 89", "Fronts 90" and "Fronts 91" cruises (Varela and FRONTS Group, 1991). For the "Canyons" and "Caco" cruises, the precision of nutrient concentration was calculated during the analysis with Quality Control Charts (QCC) using internal standards within the samples. No data about the precision for dissolved oxygen and chl $a$ analysis were reported for all the data collected.

When the precision value was not reported, the analysis precision of all samples was estimated for each cruise and parameter, using two different methods. The first method was applied when there were different kinds of duplicated samples. In these cases the precision was estimated by calculating the standard deviation: (1) of subsamples (replicates) of the same sampling bottle, assuming that the bottle is a homogeneous sample; (2) of samples from different sampling bottles closed at the same depth, assuming that the water mass is a homogeneous sample; or (3) of consecutive analysis of the same sample in the autoanalyzer.

An alternative method for calculating the analysis precision is described by Garcia et al. (1998). These authors proposed calculating the regression line of the oceanographic variables concentration versus potential $\mathrm{T}(\theta)$ and using samples that belong to the same water mass, which should be physically and chemically stable. Then, the precision is estimated as the standard deviation of the difference between the measured values and those expected from the regression. Among the different water masses present in the NW Mediterranean Sea, the most physically stable is Western Mediterranean Deep Water (WMDW, less than $1^{\circ} \mathrm{C}$ variation, Salat, 1995), which is found below $800 \mathrm{~m}$ depth. The concentration of nutrients in this water mass is fairly constant with time and depth, according to the results of previous studies (Béthoux and CopinMontégut, 1986; Béthoux et al., 1998, 2002; Moutin and Raimbault, 2002). However, there is not enough data from this water mass on all cruises. Thus, we used as an alternative the data sampled in Levantine Intermediate Water (LIW), located between 200 and $600 \mathrm{~m}$ depth, as well as in its core, characterized by a relative maximum of $\theta$ and an absolute maximum of $\mathrm{S}$ (Salat and Cruzado, 1981; Millot, 1999).

Besides assessing the analysis precision, we also compared these methodologies to check whether they can be effectively used to estimate this parameter.

\section{Nutrient analysis}

From 1982 to 2003, nutrient data were obtained by 7 analysts using 4 different autoanalyzer instruments. The nutrient analysis methodologies that were used are known only for the cruises gathered, but not for the data extracted from the databases. The analyses were based on the same general methodologies (phosphate, 
Murphy and Riley 1962; silicate, Grasshoff 1964; Hansen and Koroleff 1999; nitrite, Bendschneider and Robinson 1952; nitrate, Hansen and Koroleff 1999; ammonium, Grasshoff 1970). Some adaptations and modifications for each autoanalyzer and analysis range were applied. However, it is commonly assumed that the quality of the measurements is often more dependent on the care during the sampling and analysis process than on the variations of a given methodology (Hager et al., 1972). Ammonium data from 2003 cruises was obtained with a different methodology (Benesch and Mengelsdorf, 1972, cited by Riley et al., 1975; Bower and Holm-Hansen, 1980), using sodium salicylate instead of phenol, to avoid the use of this toxic compound (a summary of the characteristics of the analyses can be found in Appendix 2). Nutrient concentrations are given in $\mu \mathrm{mol} \mathrm{l}^{-1}$ and the range of density $\left(\sigma_{t}\right)$ in the Catalan Sea is $25.13 \mathrm{~kg} \mathrm{~m}^{-3}$ (surface waters during summer) to $29.10 \mathrm{~kg} \mathrm{~m}^{-3}$ (corresponding to WMDW). Standards were always prepared at room temperature $\left(20-25^{\circ} \mathrm{C}\right)$.

Another potential source of variability is the baseline used as a blank, which also varied during the study period. Two different baselines were used: (1) low nutrient seawater (LNSW), which is the most recommended because there is no difference in matrix between the sample and the blank (Hansen and Koroleff, 1999), and (2) artificial seawater (ASW), which in its simplest version is a solution of sodium chloride in double-distilled seawater, with the same salinity as the samples. When ASW is used as a baseline, it should be taken into account that even using the purest products (analytical grade), trace concentrations of elements of interest can be detected and must be quantified. During the analysis of surface water from summer cruises, using $38 \mathrm{~g} \mathrm{l}^{-1}$ ASW as a blank, negative peaks were found. These are nutrient-depleted waters, the negative peaks being the result of contaminated ASW. This contamination was observed using different $\mathrm{NaCl}$ batches (Merck) and corresponds to at least 0.02-0.03 $\mu \mathrm{M}$ phosphate; 0.23-0.26 $\mu \mathrm{M}$ ammonium; 0.03-0.06 $\mu \mathrm{M}$ nitrite and $0.09-0.13 \mu \mathrm{M}$ nitrate. No silicate contamination was detected. Moreover, double-distilled water can also contain nitrite ions, depending on the age of the water.

\section{Nutrient preservation}

Another major source of variability is how the samples are taken and processed. During the first cruises gathered, nutrient analyses were performed on board during the cruise, but from 1999 to 2003 nutrient samples were routinely frozen to be analyzed after the cruise (Appendix 2). When it is not possible to analyze immediately after sample collection, which would be the best option, freezing the samples is the most acceptable preservation method. However, the accuracy and precision of the analysis decreases (Stéfansson and Richards, 1963; Thayer, 1970; Strickland and Parsons,
1972; Riley et al., 1975; Venrick and Hayward, 1985; Chapman and Mostert, 1990; Avanzino and Kennedy, 1993; Gordon et al, 1993; Valderrama, 1995; Dore et al., 1996; Aminot and Kérouel, 1998; Kremling and Brügmann, 1999).

Many studies have been conducted to study the effect of freezing on nutrient samples, but no unequivocal conclusion has been reached. The variables studied in these works include the velocity of freezing or defreezing the samples, the material of the recipient, the previous filtration due to presence of plankton or suspended matter, the period of time during which the samples are kept frozen, the surface/volume ratio of the recipient and the salinity of the sample. Those studies show contradictory results regarding the effects of freezing and filtering the samples on phosphate and ammonium concentrations but seem consistent in the validity of preserving nitrate and silicate concentration, but only if the concentration of the latter does not exceed $60 \mu \mathrm{M}$. In summary, the conclusion is similar to that described by Venrick and Hayward (1985) in a bibliographic revision about preservation methods. Those authors concluded that the effectiveness of the procedure depends highly on the local biological and chemical characteristics of the water, as well as the methodology used. They therefore suggested that nutrient preservation should be considered as the last option, and if necessary each laboratory should determine the resulting error introduced.

As suggested by Venrick and Hayward (1985), we designed an experiment to test the effect of freezing samples from the NW Mediterranean Sea during a routine monthly sampling of the "Pudem" project. The results of this test will help us decide whether we can use the nutrient data that were frozen as a preservation method on the cruises gathered to build up the QC ranges of concentration for nutrients. Nutrient samples were taken from 6 different stations, at 2 different depths at each station (surface and bottom, the latter from 10 up to $40 \mathrm{~m}$ depth). Sampling tubes (polypropylene, $12 \mathrm{ml}$ ) were previously washed with $5 \% \mathrm{HCl}$ for 24 hours, distilled water (3 washes) and finally double-distilled water. Samples were filtered through a $200-\mu \mathrm{m}$ mesh to remove large zooplankton, and were preserved tightly closed in an icebox during the sampling time in an upright position. In the research centre 3 replicates of each station and depth were immediately analyzed, and 3 replicates were frozen in an upright position at $-20^{\circ} \mathrm{C}$ (the temperature at which preserved nutrient samples from the gathered cruises were frozen). Samples were stored in a freezer containing exclusively nutrient samples (no biological samples). Samples remained frozen for one week before analyses were conducted using an AA3 autoanalyzer (Bran+Luebbe). ASW was used as a baseline because this was the blank most used when nutrient samples from the cruises were frozen (Appendix 2).

During the experiment, additional precautions were taken to: (1) avoid water at the tip from reaching the 
sample, for example by drying the exterior of the tube before the sample was homogenized and introduced into the sampler; (2) keep the sample exposed to the air as short a time as possible during the analysis; and (3) avoid touching the interior of the tube and tip with the fingers.

The range of nutrient values, as well as precision (standard deviation from QCC using standards) and detection limits of the analysis (calculated following Gomez-Taylor et al., 2003) are the following: 0-0.5 $\mu \mathrm{M}, 3 \%$ and $0.006 \mu \mathrm{M}$ for phosphate analysis; $0-3$ $\mu \mathrm{M}, 1 \%$ and $0.015 \mu \mathrm{M}$ for nitrate analysis; $0-0.5 \mu \mathrm{M}$, $4 \%$ and $0.004 \mu \mathrm{M}$ for nitrite analysis; $0-3 \mu \mathrm{M}, 3 \%$ and $0.020 \mu \mathrm{M}$ for ammonium analysis; and 0-5 $\mu \mathrm{M}, 1 \%$ and $0.017 \mu \mathrm{M}$ for silicate analysis.

The statistical analysis for the determination of differences between nutrient concentration of preserved and unpreserved samples was performed with the Statistica v6.0 software package.

Assuming that few samples were frozen during onboard analysis, due to technical problems or bad weather, we also compared the nutrient concentration of the cruises on which the nutrients were preserved with those on which the nutrients were analyzed on board (unpreserved). Because we could not expect that the handling precautions taken during the experiment described above were also taken during the cruises, this additional test would help us to decide whether historical data from preserved nutrient samples were accurate enough to use them to construct the QC ranges of concentration of key bio-chemical variables in the Catalan Sea.

Since there is no information in the MEDATLAS and MATER databases on whether a preservation method of the nutrient samples was used, these data were not included in this comparison. The possible differences between cruises in which nutrients were frozen or analyzed on board were also studied with a twofactor ANOVA statistical test using Statistica v6.0.

\section{Dissolved oxygen analysis}

The dissolved oxygen analysis methodology is one of the most robust from the analytical point of view, and has remained almost unmodified since its description, in the late 19th century (Winkler, 1888). The procedure for dissolved oxygen analysis can be found in detail in Hansen (1999). Basically, the oxygen present in a water sample oxidizes $\mathrm{I}^{-}$ion to iodine, the amount of which will be determined by thiosulfate titration. The implementations of the methodology are mostly related to the automation of the final titration point, which also improves the precision of the analysis. The most important sources of error during the analysis are the oxygen present in reagents and in the blank (Culbertson et al., 1991). The concentration obtained must be corrected according to the in situ water temperature. Most of the data of dissolved oxygen gathered from the NW Mediterranean Sea were determined without automation of the final titration point. On the cruises "Pep 83", "Varimed 93", "Fans 1", "Fans 2", "Fans 3", "Hivern 99" and "Hivern 2000", a titration system with a platinum electrode was used (PEPS Group, 1986; Masó and PEPS Group, 1988; Varela and FRONTS Group, 1991; Masó and Varimed Group, 1995).

\section{Chlorophyll $a$ analysis}

All the chl $a$ concentration data collected were obtained using the methodology described in Yentsch and Menzel (1963). The most outstanding difference among the cruises gathered is the use of two different glass fibre filters; GF/C filters, with a 1.2 $\mu \mathrm{m}$ nominal pore diameter, were used during the cruises "Pep 82", "Pep 83" and "Pep 84", while GF/F filters, with a pore diameter of $0.7 \mu \mathrm{m}$, were used during the remaining cruises (PEPS Group, 1986; Masó and PEPS Group, 1988; Varela and FRONTS Group, 1991; Masó and Varimed Group, 1995). An inter-comparison experiment demonstrated that the amount of organic matter retained by the two filters was the same (Morán et al., 1999).

The precision of the present method using natural populations shows a maximum variation of $15 \%$ for ten samples. The blank calibration of the fluorometer is constant for long periods, and instrument readings are repeatable within $\pm 3 \%$ (Yentsch and Menzel, 1963). The limit of detection will depend upon the volume of seawater filtered and the sensitivity of the fluorometer. In general, the method is 5 to 10 times more sensitive than the spectrophotometric method, but it may be less accurate (Parsons et al., 1984).

In the range of years studied, the fluorometer was usually calibrated once a year using a spectrophotometer and both commercial chl $a$ (Sigma) and natural water samples from the study area. Natural samples were used to check whether there were interferences with chlorophyll $b$ or $c$. The factors obtained with the two procedures were the same (L. Arin, personal communication), so there is no interference. Also, when the fluorometer was moved to an oceanographic ship to measure the chl $a$ concentration on board, the calibration was repeated when the cruise had finished and the fluorometer was back in the laboratory.

On some cruises, just a few chl $a$ samples were taken for the calibration of the CTD fluorescence probe. Chl $a$ data obtained from a calibrated CTD fluorescence probe were not used in this study.

\section{Quality Control}

The QC was performed following Conkright et al. (1994, 2000) and Fichaut et al. (1997). Conkright et al. (1994) described a methodology to set QC for phosphate, nitrate and silicate using data from open oceanic waters. Unfortunately, because our region of study is surrounded by land and may be influenced by 
continental inputs, it does not meet the criteria used by Conkright et al. (1994) for oceanic waters. Therefore, to identify areas far from the coast to be used to build the QC, we followed Fichaut et al. (1997), which adapted the definition of open sea for the Mediterranean Sea. On these bases, areas deeper than $400 \mathrm{~m}$ are considered as open sea. We also used the standard level depths (SLD) proposed for the Mediterranean Sea by Fichaut et al. (1997), which increase the resolution at the upper layers. The SLD are those depths that have been historically most sampled, and include data comprised between up to $25 \%$ of the distance with the upper SLD and up to $75 \%$ distance with the lower SLD.

The first step for the QC description for all the biochemical variables was the determination of the frequency distribution of the data for each parameter at the closest SLD. Following Conkright et al. (1994, 2000) the initial concentration ranges were defined at each SLD by those values with a frequency higher than $0.5 \%$. However, due to the scarcity of available data of the region, this condition was changed; below $500 \mathrm{~m}$ depth the minimum frequency was set at $10 \%$ because the amount of data is scarcest; and above 500 $\mathrm{m}$, where the amount of data is higher, the threshold frequency was raised to 5\%. This criterion also allows us to better appraise the seasonal variation and proximity to the coast.

As it was observed that the concentration of nitrate and phosphate were fairly constant from $500 \mathrm{~m}$ depth to the bottom of the water column, and because the amount of data below this depth is scarce, we also merged all data below $500 \mathrm{~m}$ to set the deep initial concentration ranges of phosphate and nitrate. In the case of silicate, only data from $1400 \mathrm{~m}$ depth to bottom were averaged to set the deep initial concentration ranges of silicate, because the frequency distributions of SLD from $1400 \mathrm{~m}$ to the bottom were similar.

Chl $a$ concentration depends on the phytoplankton concentration, which grows exponentially, so the concentration intervals defined for the study of the frequency distributions were exponentially distributed. Since nitrite concentration in the NW Mediterranean Sea is tightly coupled to phytoplankton dynamics (Estrada, 1999; Lomas and Lipshultz, 2006), the concentration intervals for designing the frequency distributions of this parameter were also established exponentially.

Finally, the mean and standard deviation were calculated with the data included in the initial ranges at each SLD, and were used to calculate the final ranges using the following criteria. For stations with more than $200 \mathrm{~m}$ bottom depth (open sea and slope stations), the final concentration ranges included 2 standard deviations above and below the mean at each SLD, instead of 3 standard deviations as described in Conkright et al. (1994, 2000). However, to the first $100 \mathrm{~m}$ depth data, final ranges were calculated as 3 standard deviations because this layer, which includes the DCM, is biological and physically more dynamic. For stations with less than $200 \mathrm{~m}$ bottom depth (continental shelf and coastal stations), to include possible variations due to terrestrial influences, the final concentration ranges were set to three standard deviations below $100 \mathrm{~m}$ depth and 4 standard variations in the upper $100 \mathrm{~m}$ depth. These final concentration ranges constitute the QC for data from the NW Mediterranean Sea. Each value in the database was flagged with a " 0 " if it was included within the final concentration ranges, with a "1" if it was above the upper limit, and with a " 2 " if it was below the lower limit.

Using these criteria, it was observed that data from the photic layer corresponding to mixed waters in winter were mostly flagged with " 1 ," except for phosphate and dissolved oxygen, so we concluded that the obtained overall ranges could not be applied to mixed winter surface waters. To resolve this problem, the degree of stratification was calculated for each individual station of each cruise with the following methodology. First, the $100 \mathrm{~m}$ depth vertical stratification index (VDSI100) was calculated following Estrada (1999)

$$
\operatorname{VDSI} 100=\sum_{i=1}^{n} N_{i}^{2} \Delta z_{i}
$$

where $\mathrm{z}$ is depth, $\mathrm{N}_{\mathrm{i}}$ is the Brunt-Väisälä frequency $\left(\mathrm{s}^{-1}\right)$ between $\mathrm{z}_{\mathrm{i}-1}$ and $\mathrm{z}_{\mathrm{i}}$, and $\mathrm{n}=100$. $\mathrm{N}$ was calculated as in Pond and Pickard (1983)

$$
\mathrm{N}^{2}=\mathrm{g}^{*}\left[-(1 / \rho) *\left(\delta \sigma_{\mathrm{t}} / \delta \mathrm{z}\right)\right]
$$

where $\mathrm{g}$ is the gravity $\left(\mathrm{m} \mathrm{s}^{-2}\right), \rho$ is the density of the water, and $\sigma_{\mathrm{t}}$ is the density as $\sigma$-T (units of both are $\mathrm{Kg} \mathrm{m}^{-3}$ ). As expected, the calculated VDSI100 values showed a strong seasonal variability (Fig. 2). Then, we designed a stratification index based on the observations in Figure 2. Stations with VDSI100 lower than 5 (winter conditions) were given a " 1 ," whereas those with a VDSI100 higher than 30 (summer conditions) were given a "3". Stratification indices "2" and "4," which correspond to spring and autumn transition periods, were assigned following the criteria described in Table 2. Each collected profile was thus identified with a stratification index (from 1 to 4 ) and data from profiles corresponding to 1 were used to set the winter concentration ranges. New QCs for stations with a stratification index of 1 were defined following the same methodology. However, due to the low amount of data, the initial ranges were set using values with a frequency higher than $10 \%$ at all the SLD.

Finally, because VDSI100 is calculated from variations in density in the water column, which depends on the $\mathrm{T}$ and $\mathrm{S}$, an additional study about the contribution of $\mathrm{T}$ and $\mathrm{S}$ to the stratification was performed using the following equations:

$$
\begin{gathered}
\mathrm{N}^{2}=\mathrm{N}^{2}{ }_{\mathrm{T}}+\mathrm{N}^{2} \mathrm{~S} \\
\mathrm{~N}^{2}{ }_{\mathrm{T}}=\mathrm{g} *\left[-(1 / \rho)^{*}(\delta \rho / \delta \mathrm{T})^{*}(\delta \mathrm{T} / \delta \mathrm{z})\right] \\
\mathrm{N}^{2}{ }_{\mathrm{S}}=\mathrm{g} *\left[(1 / \rho)^{*}(\delta \rho / \delta \mathrm{S})^{*}(\delta \mathrm{S} / \delta \mathrm{z})\right]
\end{gathered}
$$




\section{RESULTS}

\section{Analytical precision}

The analytical precisions estimated with duplicated analyses and QCC during the cruises, and following Garcia et al. (1998), are shown in Tables 3 and 4. The precision is presented as the standard deviation (s) and as the coefficient of variation $(\mathrm{CV}$ in \%) of the analysis, because these are the customary ways to report it. However, one needs to be aware that the CV depends on the sample concentration, so the resulting value is less stable than the standard deviation value. It is because of this that in deep waters, where the concentrations are high and constant (CV data not shown), the lowest $\mathrm{CV}$ for phosphate, nitrate, silicate and dissolved oxygen analyses are obtained using the methodology of Garcia et al. (1998). This explains why in the same cruise, lower (better) precision values were found when data from the WMDW were used, whereas higher (worse) precision values resulted when data only from the core of the LIW or all data in the LIW were used. This can also be observed in all the cruises studied, when the precisions obtained using the different water masses are compared (Table 4).

The overall mean precision calculated for inorganic nutrients and dissolved oxygen analysis is lower when duplicated samples and QCC are used (last row in Table 3) than when it is calculated with WMDW data, following Garcia et al. (1998) (last row in Table 4), except for nitrite, whose averages are similar.

The precisions calculated using duplicated samples from the same sampling bottle were unusually high for all nutrients in the "Meso 95" cruise and for silicate in the "Varimed 95" cruise. Removing these unusual results, we obtained the following ranges and means of analysis precisions using data from Table 3: phosphate $<0.01-0.04 \mu \mathrm{M}$, mean $0.02 \mu \mathrm{M}$; nitrate $0.03-0.16$ $\mu \mathrm{M}$, mean $0.11 \mu \mathrm{M}$; nitrite $<0.01-0.02 \mu \mathrm{M}$, mean 0.02 $\mu \mathrm{M}$; ammonium 0.04-0.43 $\mu \mathrm{M}$, mean $0.14 \mu \mathrm{M}$; silicate $0.02-0.25 \mu \mathrm{M}$, mean $0.12 \mu \mathrm{M}$; and dissolved oxygen $0.01-0.21 \mathrm{ml} \mathrm{l}^{-1}$, mean $0.11 \mathrm{ml} \mathrm{l}^{-1}$.

Analysis precision for chl $a$ analyses could only be estimated following Garcia et al. (1998); its range throughout the cruises studied using data from the WMDW was 0.01-0.03 $\mu \mathrm{g}^{-1}$ (Table 4).

\section{Nutrient preservation 1. Laboratory experiment}

Measurements of preserved and unpreserved nutrient samples were significantly correlated for all the nutrients $(P<0.01$, Table 5). Changes in nutrient concentrations due to the preservation process were studied with a non-parametric ANOVA test for phosphate, nitrite and ammonium, whose data sets were not normally distributed (Kolmogorov-Smirnov test: $P<0.01$ for phosphate and $P<0.05$ for nitrite and ammonium), and a parametric ANOVA test for nitrate and silicate. The chl $a$ concentration range of the samples was $0.63-$ $0.89 \mu \mathrm{g}^{-1}$. Table 5 shows the mean concentration of preserved and unpreserved samples of our experiment. Nutrient concentrations were not significantly affected by the freezing process except for nitrite, which had a concentration significantly lower in preserved samples $(P<0.05)$. However, ammonium results showed the highest relative error $(18.2 \%)$ and the highest standard deviation among frozen samples $(0.23 \mu \mathrm{M})$ (Table 5).

The standard deviation among frozen samples was higher than that calculated in fresh samples (Table 5), as has already been observed (DeGobbis, 1973; Gordon et

TABLE 3. - Analysis precision calculated using different methods: reported (1, PEPS Group, 1986) and calculated using different samples collected at the same depth (2, without any information about the Niskin bottle number); different samples collected from the same sampling Niskin bottle (3); different samples collected from different Niskin bottles closed at the same depth (4); consecutive analysis of the same sample (5); and QCC using standards inserted among the samples (6). s, standard deviation (in $\mu \mathrm{M}$ for nutrients and ml $\mathrm{l}^{-1}$ for dissolved oxygen); $\mathrm{CV}$, coefficient of variation (in \%); $\mathrm{n}$, amount of data. The mean (last row) was calculated with all the calculated precisions

\begin{tabular}{|c|c|c|c|c|c|c|c|c|c|c|c|c|c|c|c|c|c|c|c|}
\hline \multirow[t]{2}{*}{ Cruise } & \multirow[t]{2}{*}{ Metho } & \multicolumn{3}{|c|}{ Phosphate } & \multicolumn{3}{|c|}{ Nitrate } & \multicolumn{3}{|c|}{ Nitrite } & \multicolumn{3}{|c|}{ Ammonium } & \multicolumn{3}{|c|}{ Silicate } & \multicolumn{3}{|c|}{$\begin{array}{l}\text { Dissolved } \\
\text { oxygen }\end{array}$} \\
\hline & & $\mathrm{s}$ & $\mathrm{CV}$ & $\mathrm{n}$ & $\mathrm{s}$ & $\mathrm{CV}$ & $\mathrm{n}$ & s & $\mathrm{CV}$ & $\mathrm{n}$ & $\mathrm{s}$ & $\mathrm{CV}$ & $\mathrm{n}$ & $\mathrm{s}$ & $\mathrm{CV}$ & $\mathrm{n}$ & $\mathrm{s}$ & $\mathrm{CV}$ & $\mathrm{n}$ \\
\hline Fronts $89,90,91$ & 11 & & 10 & & & 1 & & & 0.1 & & & 1 & & & 0.1 & & & & \\
\hline Varimed 93 I & 2 & & & & 0.08 & 9 & 16 & 0.01 & 16 & 16 & & & & 0.15 & 9 & 16 & 0.21 & 4 & 6 \\
\hline Varimed 93 II & 2 & & & & 0.08 & 7 & 43 & 0.02 & 11 & 43 & & & & 0.17 & 12 & 41 & 0.18 & 3 & 10 \\
\hline Varimed 93 III & 2 & & & & 0.16 & 12 & 172 & 0.02 & 12 & 173 & & & & 0.12 & 9 & 173 & 0.16 & 3 & 57 \\
\hline Varimed 95 & 3 & $<0.01$ & 7 & 22 & 0.08 & 13 & 22 & 0.01 & 9 & 22 & & & & 0.52 & 38 & 22 & & & \\
\hline Meso 95 & 3 & & & & 0.65 & 30 & 6 & 0.07 & 14 & 6 & & & & 0.44 & 18 & 6 & 0.30 & 5 & 6 \\
\hline Varimed 95 & 4 & 0.01 & 12 & 64 & 0.15 & 22 & 64 & 0.02 & 12 & 64 & & & & 0.17 & 27 & 64 & & & \\
\hline Meso 95 & 4 & & & & & & & & & & & & & & & & 0.07 & 2 & 4 \\
\hline Fans 1 & 4 & 0.03 & 31 & 68 & 0.06 & 18 & 68 & $<0.01$ & 7 & 68 & & & & 0.07 & 5 & 68 & 0.07 & 1 & 15 \\
\hline Fans 2 & 4 & 0.02 & 24 & 276 & 0.09 & 3 & 324 & 0.01 & 5 & 324 & & & & 0.10 & 3 & 324 & 0.01 & 0 & 38 \\
\hline Fans 3 & 4 & 0.04 & 36 & 52 & 0.09 & 12 & 126 & 0.01 & 11 & 125 & & & & 0.12 & 5 & 134 & 0.07 & 1 & 40 \\
\hline Hivern 1999 & 5 & 0.01 & 8 & 252 & 0.08 & 4 & 226 & 0.01 & 9 & 254 & 0.04 & 5 & 254 & 0.16 & 5 & 235 & & & \\
\hline Hivern 2000 & 5 & 0.01 & 3 & 220 & 0.05 & 1 & 216 & 0.01 & 9 & 220 & 0.08 & 12 & 220 & 0.09 & 2 & 195 & & & \\
\hline Canyons I & 5 & 0.02 & 6 & 289 & 0.08 & 6 & 297 & 0.01 & 8 & 296 & 0.05 & 11 & 297 & 0.12 & 10 & 296 & & & \\
\hline Canyons II & 5 & $<0.01$ & 7 & 290 & 0.07 & 5 & 291 & $<0.01$ & 7 & 291 & & & & 0.02 & 2 & 290 & & & \\
\hline Canyons II - IV & 6 & 0.03 & 6 & 92 & 0.10 & 5 & 110 & 0.02 & 5 & 104 & 0.43 & 16 & 34 & 0.25 & 5 & 92 & & & \\
\hline Caco 1,2 & 6 & 0.01 & 3 & 90 & 0.03 & 2 & 84 & 0.01 & 5 & 83 & 0.09 & 6 & 89 & 0.02 & 1 & 90 & & & \\
\hline Mean & & 0.02 & 23 & 1715 & 0.11 & 9 & 2065 & 0.02 & 9 & 2089 & 0.14 & 11 & 894 & 0.12 & 8 & 2046 & 0.11 & 2 & 176 \\
\hline
\end{tabular}


TABLE 4. - Analysis precision estimated for each cruise and oceanographic variable using the methodology described in Garcia et al. (1988) using data from WMDW, from the core of the LIW $(*)$, and using all LIW data $(* *)$. The mean value was calculated using all the data at the WMDW. s, standard deviation (same units as Table 4, $\mu \mathrm{g} \mathrm{1^{-1 }}$ for chl $a$ ); $\mathrm{n}$, amount of data.

\begin{tabular}{|c|c|c|c|c|c|c|c|c|c|c|c|c|c|c|}
\hline \multirow[t]{2}{*}{ Cruise } & \multicolumn{2}{|c|}{ Phosphate } & \multicolumn{2}{|c|}{ Nitrate } & \multicolumn{2}{|c|}{ Nitrite } & \multicolumn{2}{|c|}{ Ammonium } & \multicolumn{2}{|c|}{ Silicate } & \multicolumn{2}{|c|}{ Dissolved $\mathrm{O}_{2}$} & \multicolumn{2}{|c|}{ Chlorophyll $a$} \\
\hline & $\mathrm{s}$ & $\mathrm{n}$ & $\mathrm{s}$ & $\mathrm{n}$ & $\mathrm{s}$ & $\mathrm{n}$ & $\mathrm{s}$ & $\mathrm{n}$ & $\mathrm{s}$ & $\mathrm{n}$ & $\mathrm{s}$ & $\mathrm{n}$ & $\mathrm{s}$ & $\mathrm{n}$ \\
\hline PEP 82 & 0.01 & 5 & 0.14 & 7 & 0.00 & 8 & $0.01 *$ & 4 & 0.30 & 8 & 0.13 & 8 & $0.02 *$ & 10 \\
\hline PEP 83 & 0.07 & 12 & 0.54 & 12 & 0.01 & 12 & $0.03 *$ & 15 & 0.53 & 12 & 0.06 & 12 & 0.00 & 8 \\
\hline PEP 84 & 0.03 & 10 & 0.57 & 10 & 0.02 & 10 & $0.14^{*}$ & 4 & $0.64 *$ & 46 & 0.28 & 10 & $0.01 *$ & 9 \\
\hline Fronts-3-85 & 0.12 & 13 & 0.45 & 13 & 0.01 & 13 & & & 0.44 & 13 & 0.16 & 13 & 0.01 & 7 \\
\hline Fronts-6-85 & 0.06 & 31 & 0.73 & 31 & $0.09 * *$ & 16 & & & 0.75 & 31 & 0.23 & 31 & 0.01 & 14 \\
\hline PEP 86 & & & 0.46 & 36 & $0.02 * *$ & 33 & 0.14 & 35 & 0.24 & 37 & 0.21 & 37 & 0.03 & 9 \\
\hline Fronts $11-86$ & & & 0.13 & 6 & 0.00 & 31 & 0.04 & 6 & 0.22 & 6 & 0.01 & 6 & & \\
\hline PEP 87 & 0.05 & 34 & 0.47 & 33 & 0.02 & 37 & $0.14^{*}$ & 12 & 0.31 & 34 & 0.04 & 34 & 0.02 & 5 \\
\hline Fronts 89 & $0.03 *$ & 15 & $0.33 *$ & 16 & & & $0.27 *$ & 16 & $0.41 *$ & 16 & $0.08 *$ & 17 & $0.08 * *$ & 61 \\
\hline Fronts 90 & $0.04 *$ & 8 & 0.03 & 4 & 0.01 & 6 & $0.30 *$ & 8 & 0.65 & 6 & 0.03 & 6 & 0.00 & 4 \\
\hline Fronts 91 & & & $0.31 * *$ & 71 & & & & & $0.20 * *$ & 3 & $0.07 * *$ & 3 & & \\
\hline Fronts 92 & $0.04 *$ & 15 & $0.47 *$ & 16 & & & $0.13^{*}$ & 10 & $0.48 *$ & 16 & $0.17 *$ & 16 & $0.07 *$ & 15 \\
\hline Varimed 93 I & & & 0.28 & 115 & 0.02 & 34 & & & 0.35 & 113 & 0.05 & 117 & & \\
\hline Varimed 93 II & & & 0.14 & 25 & 0.01 & 4 & & & 0.56 & 25 & 0.21 & 34 & & \\
\hline Varimed 93 III & & & 0.10 & 23 & 0.06 & 115 & & & 0.43 & 23 & 0.10 & 7 & & \\
\hline Varimed 95 & 0.02 & 68 & 0.08 & 73 & $0.01 *$ & 18 & & & 0.26 & 73 & & & $0.05 * *$ & 111 \\
\hline Meso 95 & & & 0.45 & 98 & 0.06 & 23 & & & 0.55 & 99 & $0.14 *$ & 50 & & \\
\hline Fans 1 & 0.02 & 15 & 0.04 & 15 & 0.01 & 73 & & & 0.06 & 15 & 0.18 & 10 & $0.06 * *$ & 77 \\
\hline Fans 2 & 0.01 & 23 & 0.09 & 23 & $0.00 *$ & 43 & & & 0.20 & 23 & 0.05 & 26 & $0.05 * *$ & 94 \\
\hline Fans 3 & 0.05 & 10 & 0.23 & 24 & 0.01 & 15 & & & 0.34 & 9 & $0.06^{*}$ & 27 & $0.07 * *$ & 122 \\
\hline Hivern 1999 & 0.07 & 24 & 0.84 & 10 & 0.00 & 24 & $0.22 *$ & 14 & 1.09 & 17 & $0.07 *$ & 4 & $0.01 *$ & 4 \\
\hline Hivern 2000 & 0.05 & 94 & 0.91 & 93 & 0.01 & 10 & 0.31 & 94 & 1.11 & 94 & 0.13 & 62 & 0.02 & 34 \\
\hline Canyons I & $0.05 *$ & 15 & 0.79 & 20 & 0.02 & 24 & $0.44 *$ & 15 & 0.99 & 20 & & & $0.13 * *$ & 62 \\
\hline Canyons II & $0.02 *$ & 20 & $1.02 *$ & 20 & 0.02 & 94 & & & 0.15 & 20 & & & $0.03 * *$ & 65 \\
\hline Canyons III & 0.04 & 17 & 0.86 & 17 & 0.01 & 20 & & & 0.71 & 17 & & & $0.03 * *$ & 99 \\
\hline Canyons IV & $0.04 *$ & 9 & $0.65 *$ & 9 & 0.03 & 17 & & & 0.28 & 9 & & & $0.04 * *$ & 34 \\
\hline Caco 1 & 0.03 & 4 & 0.47 & 4 & 0.01 & 4 & 0.21 & 16 & 0.47 & 4 & & & $0.04 * *$ & 72 \\
\hline Caco 2 & 0.02 & 3 & 0.15 & 3 & 0.00 & 3 & 0.30 & 16 & 0.18 & 3 & & & $0.05 * *$ & 76 \\
\hline Mean (WMDW) & 0.04 & 339 & 0.39 & 680 & 0.02 & 577 & 0.20 & 142 & 0.46 & 655 & 0.12 & 413 & 0.01 & 81 \\
\hline
\end{tabular}

TABLE 5. - Summary of the results of the experiment on the freezing effect on seawater nutrient concentration $(\mu \mathrm{M})$. $P$-value for all the correlations $<0.01$. * indicates the existence of statistically significant differences $(P<0.05)$ between the mean concentration of freshly analyzed samples and that of frozen samples. $n=16$.

\begin{tabular}{|c|c|c|c|c|c|}
\hline & Phosphate & Nitrate & Nitrite & Ammonium & Silicate \\
\hline Correlation coefficient & 0.97 & 0.99 & 0.80 & 0.96 & 0.96 \\
\hline Mean fresh concentration & 0.16 & 1.88 & 0.35 & 2.14 & 1.96 \\
\hline Mean frozen concentration & 0.17 & 1.85 & $0.31 *$ & 2.53 & 1.91 \\
\hline Difference & 0.01 & 0.03 & 0.04 & 0.39 & 0.05 \\
\hline Relative error frozen samples & $6.3 \%$ & $-1.6 \%$ & $-11.4 \%$ & $18.2 \%$ & $-2.5 \%$ \\
\hline SD fresh samples (nM) & 5 & 10 & 5 & 77 & 42 \\
\hline SD frozen samples (nM) & 15 & 107 & 22 & 227 & 118 \\
\hline
\end{tabular}

al., 1993; Dore et al., 1996). The standard deviation of freshly analyzed samples was similar to that calculated from QCC using standards, except for ammonium and silicate which had higher standard deviations (about 4 and 2.5 times higher respectively).

\section{Nutrient preservation 2. Comparison of cruise samples: on board analysis versus frozen nutrient samples}

The study of the existence of statistically significant differences between the concentration of preserved and unpreserved nutrient samples is difficult. Because the concentration of nutrients changes with depth and season, the water column nutrient concentration can be different. We therefore applied a factorial ANOVA test to the data, the factors being the preservation of the sample, the SLD, and the degree of stratification of the water column. The results showed that there were statistically significant differences in the concentration of nutrients between previously frozen samples and unpreserved ones $(P>0.05)$. However a general pattern could not be found, because there were no differences at all the SLDs; when there were differences, sometimes the concentration was higher and sometimes it was lower.

Because the proportion of samples at each SLD is similar for cruises on which nutrient samples were frozen and those on which nutrient samples were analyzed on board, we estimated the relative error due to the freezing process in the same way as in the laboratory experiment. Table 6 shows the mean concentration of samples preserved and unpreserved for the cruises under study, as well as the relative error as a result of the preservation of the nutrient samples. 
TABLE 6. - Summary of the results on the freezing effect on seawater nutrient concentration $(\mu \mathrm{M})$ using the data of the cruises collected. $P$-value for all adjusted $r^{2}<0.01$. * indicates the existence of statistically significant differences $(P<0.01)$ between the mean concentration of freshly (on board) analyzed samples and frozen nutrient samples. Nitrate average from frozen samples does not include 19 values higher than $15 \mu \mathrm{M}$ from the "Hivern 1999" cruise.

\begin{tabular}{|c|c|c|c|c|c|}
\hline & Phosphate & Nitrate & Nitrite & Ammonium & Silicate \\
\hline Adjusted $\mathrm{R}^{2}$ & 0.51 & 0.80 & 0.18 & 0.15 & 0.78 \\
\hline Mean fresh concentration & 0.18 & 3.06 & 0.13 & 0.48 & 2.91 \\
\hline Number of fresh samples & 6065 & 10856 & 9865 & 2562 & 10897 \\
\hline Mean frozen concentration & $0.19 *$ & $3.23 *$ & $0.10 *$ & $0.96 *$ & 2.97 \\
\hline Number of frozen samples & 2928 & 3097 & 3119 & 2382 & 3116 \\
\hline Difference fresh-frozen & 0.01 & 0.17 & 0.03 & 0.48 & 0.06 \\
\hline Relative error of frozen samples & $6.2 \%$ & $5.8 \%$ & $-21.5 \%$ & $102.1 \%$ & $1.8 \%$ \\
\hline
\end{tabular}

Several trends were found that agree with the results of the laboratory experiment. First, the concentration of nitrite decreased, while the concentration of phosphate and ammonium increased. Second, the magnitude of the error was lower for silicate and nitrate, the same for phosphate, and higher for nitrite and ammonium.

For phosphate, the difference of mean concentrations was the same as that calculated in the laboratory experiment, and was similar to the mean analysis precision (Table 3, last row). In addition, the relative error was also the same (6\%, Tables 5 and 6). For ammonium, the mean concentration of preserved samples was twice that of unpreserved ones (relative error 102\%). The mean concentration of nitrite in preserved samples was $0.03 \mu \mathrm{M}$ lower than the mean concentration in unpreserved samples, the same as in the laboratory experiment. However, as the mean value was lower, the relative error was higher $(21.5 \%)$.

For silicate, differences between the mean concentration of preserved and unpreserved samples were not statistically significant. The differences between means and the relative error were similar to those found in the laboratory experiment $(0.05-0.06 \mu \mathrm{M}$ and $2 \%$ respectively), but positive (Tables 5 and 6).

Preserved nitrate samples also behaved contrary to what was found in the laboratory experiment: the mean concentration increased in $0.3 \mu \mathrm{M}$, which represented a relative error of $9.2 \%$. However, nitrate concentrations of the "Hivern 1999" cruise, on which nutrient samples were preserved, contained data higher than $15 \mu \mathrm{M}$ that could not be found in any of the other cruises. After they had been removed from the analysis, the mean nitrate concentration from preserved samples was $3.23 \mu \mathrm{M}$, and the relative error was lowered to $5.8 \%$ $(\mathrm{n}=3097)$.

Due to the high error found when ammonium samples are preserved, comparing data from the cruises and from the results of the laboratory experiment, data of ammonium concentration from preserved samples were not used to define the $\mathrm{QC}$ concentration ranges of ammonium in the NW Mediterranean Sea.

\section{Water column stratification}

According to our results, the contribution of the $\mathrm{T}$ to the stratification of the water column is higher than the contribution of S ( $75 \%$ and $25 \%$, respectively).
These results are consistent with previous studies that state that the vertical stratification is controlled by the T (Velásquez, 1997). During spring and summer, the upper layer is warmed and a mixed layer is formed. This mixed layer is broken up in autumn and winter because of convective processes (vertical mixing), due to an increase in the wind intensity as well as storms (Salat, 1996; Send et al., 1999). During winter, the $\mathrm{T}$ of the whole water column is around $12^{\circ} \mathrm{C}$, and even thermal inversion can be observed (Salat, 1996). Therefore, when the water mass was highly mixed, the $\mathrm{T}$ contribution to the stratification decreased, but it was still higher than the $\mathrm{S}$ contribution. While highest surface $\mathrm{S}$ values were found in winter, in general this variable does not show such evident changes throughout the year as $\mathrm{T}$. The highest $\mathrm{S}$ values in winter are a consequence of the evaporation due to the effect of strong winds, and due to mixing with deeper waters that are saltier than the surface ones (Salat, 1996). Only the $\mathrm{S}$ contribution was important to the vertical stratification at stations close to the coast and to the Ebro Delta.

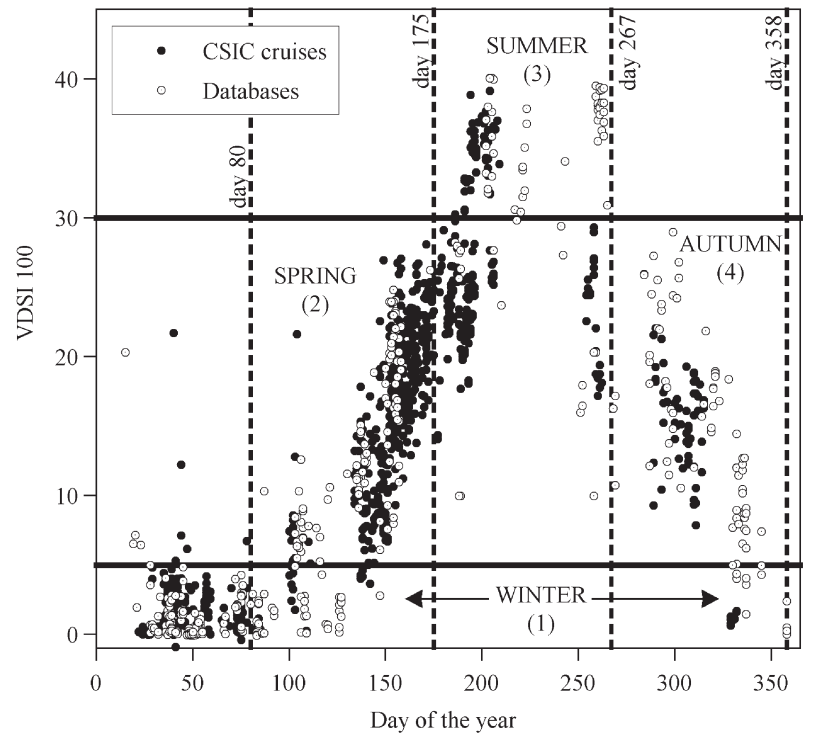

FIG. 2. - Variation throughout the year of the vertical stratification index at $100 \mathrm{~m}$. CSIC Cruises, data from the cruises gathered for this study; Databases, data from MEDATLAS and MATER databases. Between brackets, stratification index that represents each season of the year. 
TABLE 7. - Phosphate concentration $(\mu \mathrm{M})$ ranges in the NW Mediterranean Sea. SLD, Standard Level Depth; LR, Lower Range; UR, Upper Range; Coast and continental shelf stations have a bottom depth less than $200 \mathrm{~m}$. Slope and open sea stations have a bottom depth larger than $200 \mathrm{~m}$. $\mathrm{n}$, amount of data within the range; \% n range, proportion of the total amount of data included in the range at each SLD.

\begin{tabular}{|c|c|c|c|c|c|c|}
\hline \multirow[t]{2}{*}{ SLD } & \multicolumn{2}{|c|}{$\begin{array}{l}\text { Slope and } \\
\text { open sea }\end{array}$} & \multicolumn{2}{|c|}{$\begin{array}{c}\text { Coast and } \\
\text { continental shelf }\end{array}$} & \multirow[t]{2}{*}{$\mathrm{n}$ range } & \multirow[t]{2}{*}{$\begin{array}{c}\% \mathrm{n} \\
\text { range }\end{array}$} \\
\hline & LR & UR & LR & UR & & \\
\hline 0 & 0.00 & 0.30 & 0.00 & 0.37 & 357 & 90.2 \\
\hline 5 & 0.00 & 0.30 & 0.00 & 0.37 & 449 & 93.5 \\
\hline 10 & 0.00 & 0.31 & 0.00 & 0.39 & 298 & 87.9 \\
\hline 20 & 0.00 & 0.30 & 0.00 & 0.37 & 472 & 90.1 \\
\hline 30 & 0.00 & 0.29 & 0.00 & 0.36 & 498 & 92.6 \\
\hline 40 & 0.00 & 0.30 & 0.00 & 0.37 & 497 & 90.5 \\
\hline 50 & 0.00 & 0.29 & 0.00 & 0.36 & 486 & 92.6 \\
\hline 60 & 0.00 & 0.34 & 0.00 & 0.41 & 407 & 90.4 \\
\hline 80 & 0.00 & 0.36 & 0.00 & 0.44 & 896 & 89.3 \\
\hline 100 & 0.00 & 0.42 & 0.00 & 0.51 & 809 & 89.8 \\
\hline 120 & 0.06 & 0.43 & 0.00 & 0.52 & 300 & 90.6 \\
\hline 160 & 0.06 & 0.44 & 0.00 & 0.54 & 368 & 89.3 \\
\hline 200 & 0.10 & 0.49 & 0.03 & 0.58 & 527 & 89.5 \\
\hline 250 & 0.13 & 0.50 & & & 195 & 88.6 \\
\hline 300 & 0.17 & 0.52 & & & 289 & 79.8 \\
\hline 400 & 0.28 & 0.51 & & & 339 & 73.4 \\
\hline 500 & 0.30 & 0.52 & & & 205 & 67.4 \\
\hline 600 & 0.32 & 0.52 & & & 191 & 79.9 \\
\hline 800 & 0.31 & 0.52 & & & 196 & 81.3 \\
\hline 1000 & 0.30 & 0.50 & & & 128 & 71.1 \\
\hline 1200 & 0.29 & 0.49 & & & 37 & 82.2 \\
\hline 1400 & 0.32 & 0.50 & & & 16 & 55.2 \\
\hline 1600 & 0.31 & 0.50 & & & 49 & 83.1 \\
\hline 1800 & 0.30 & 0.49 & & & 22 & 91.7 \\
\hline 2000 & 0.29 & 0.48 & & & 39 & 90.7 \\
\hline 2500 & 0.31 & 0.50 & & & 21 & 100.0 \\
\hline$\geq 500$ & 0.31 & 0.51 & & & 904 & 76.3 \\
\hline Total & & & & & 8091 & 87.3 \\
\hline
\end{tabular}

The stratification of the water column starts at the beginning of April, and highly stratified stations can already be observed at the beginning of July (Fig. 2). The stratification lasts between 4 and 5 months from the start of its formation (around the 100th day of the year) to the beginning of its disappearance (around the 250th day), the same length as described for the thermocline presence in the Mediterranean Sea (Duarte et al., 1999).

\section{QC concentration ranges}

Phosphate concentration in open sea surface waters $(0-50 \mathrm{~m})$ of the NW Mediterranean Sea ranged between 0.0 and $0.3 \mu \mathrm{M}$ (Table 7). From 50 to $400-500 \mathrm{~m}$ depth, the concentration increased monotonically towards the maximum ranges measured in the NW Mediterranean Sea. The concentration range from $400-500 \mathrm{~m}$ depth to the bottom of the basin was between 0.3 and $0.5 \mu \mathrm{M}$. In coastal and continental shelf waters, concentration ranges followed the same pattern, except that the upper limit was $0.1 \mu \mathrm{M}$ higher, and the lower one was $0.0 \mu \mathrm{M}$ at all the SLDs.

On the continental shelf, phosphate data above the described ranges were located in front of the Ebro Delta, as well as in front of the city of Barcelona. At open sea stations, there was no clear pattern of localization
TABLE 8. - Nitrate concentration $(\mu \mathrm{M})$ ranges in the NW Mediterranean Sea in stratified water columns (stratification coefficient $=2$, 3 and 4). Headers as in Table 7.

\begin{tabular}{|c|c|c|c|c|c|c|}
\hline \multirow[t]{2}{*}{ SLD } & \multicolumn{2}{|c|}{$\begin{array}{l}\text { Slope and } \\
\text { open sea }\end{array}$} & \multicolumn{2}{|c|}{$\begin{array}{c}\text { Coast and } \\
\text { continental shelf }\end{array}$} & \multirow[t]{2}{*}{$\mathrm{n}$ range } & \multirow[t]{2}{*}{$\begin{array}{l}\% \mathrm{n} \\
\text { range }\end{array}$} \\
\hline & $\mathrm{LR}^{\mathrm{r}}$ & UR & LR & UR & & \\
\hline 0 & 0.00 & 0.76 & 0.00 & 0.95 & 234 & 93.2 \\
\hline 5 & 0.00 & 0.85 & 0.00 & 1.07 & 472 & 84.3 \\
\hline 10 & 0.00 & 0.78 & 0.00 & 0.98 & 342 & 94.5 \\
\hline 20 & 0.00 & 0.83 & 0.00 & 1.04 & 512 & 88.0 \\
\hline 30 & 0.00 & 0.86 & 0.00 & 1.07 & 483 & 88.8 \\
\hline 40 & 0.00 & 1.36 & 0.00 & 1.71 & 529 & 81.1 \\
\hline 50 & 0.00 & 1.98 & 0.00 & 2.49 & 457 & 82.2 \\
\hline 60 & 0.00 & 4.25 & 0.00 & 5.29 & 550 & 82.5 \\
\hline 80 & 0.00 & 7.64 & 0.00 & 9.31 & 1106 & 91.4 \\
\hline 100 & 0.13 & 7.95 & 0.00 & 9.26 & 852 & 84.6 \\
\hline 120 & 2.86 & 7.74 & 1.64 & 8.95 & 334 & 85.9 \\
\hline 160 & 3.15 & 8.26 & 1.87 & 9.53 & 344 & 84.7 \\
\hline 200 & 3.50 & 8.96 & 2.13 & 10.32 & 520 & 85.4 \\
\hline 250 & 5.13 & 9.17 & & & 153 & 84.1 \\
\hline 300 & 5.41 & 9.79 & & & 351 & 86.9 \\
\hline 400 & 6.87 & 9.68 & & & 362 & 79.6 \\
\hline 500 & 7.83 & 9.59 & & & 270 & 72.4 \\
\hline 600 & 8.16 & 9.37 & & & 138 & 61.3 \\
\hline 800 & 8.17 & 9.40 & & & 196 & 74.2 \\
\hline 1000 & 8.14 & 9.33 & & & 164 & 66.9 \\
\hline 1200 & 8.19 & 9.16 & & & 35 & 70.0 \\
\hline 1400 & 7.92 & 9.27 & & & 27 & 81.8 \\
\hline 1600 & 8.01 & 9.44 & & & 57 & 68.7 \\
\hline 1800 & 8.06 & 928 & & & 20 & 76.9 \\
\hline 2000 & 8.05 & 9.32 & & & 35 & 79.5 \\
\hline 2500 & 8.00 & 9.07 & & & 17 & 89.5 \\
\hline$\geq 500$ & 8.03 & 9.43 & & & 959 & 70.4 \\
\hline Total & & & & & 8560 & 83.9 \\
\hline
\end{tabular}

of values above and below the phosphate concentration ranges found.

At stratified stations, nitrate concentration ranges in open sea surface waters above $30 \mathrm{~m}$ depth in the NW Mediterranean Sea were between 0.0 and around $0.8 \mu \mathrm{M}$ (Table 8 ). From 40 to $300 \mathrm{~m}$ the concentration increased constantly and the ranges became narrower. Below $500 \mathrm{~m}$, nitrate concentration ranges showed little variation, between 8.0 and $9.4 \mu \mathrm{M}$. In coastal and continental shelf waters, the upper limit of the nitrate concentration range increased up to $1.0 \mu \mathrm{M}$ at the surface and up to $10.3 \mu \mathrm{M}$ at $200 \mathrm{~m}$ depth.

In mixed water columns, surface nitrate concentration ranges were wider than those described above, and nitrate concentrations were between 0.0 and $3.5 \mu \mathrm{M}$ (Table 9). Nitrate concentration ranges in deep waters were similar to those described for the rest of the year. Nitrate concentration ranges in mixed water column stations in coastal and continental shelf surface waters (0-30 m depth) were from 0.0 to $4-4.5 \mu \mathrm{M}$. At $200 \mathrm{~m}$ depth, the concentration ranges were between 1.3 and $7.8 \mu \mathrm{M}$ (Table 9).

Coastal and continental shelf stations with nitrate data above the ranges were located near the Ebro Delta. Outside the continental shelf in front of the city of Tarragona (see Fig. 1), where the continental shelf widens, data from several cruises ("Fronts 89", "Meso 95", "Fans 1", "Fans 2", "Fans 3", "Caco 1" and "Caco 2") were below the described ranges at all depths. 
TABLE 9. - Nitrate concentration $(\mu \mathrm{M})$ ranges in the NW Mediterranean Sea in mixed water columns (stratification coefficient $=1$ ). Headers as in Table 7.

\begin{tabular}{|c|c|c|c|c|c|c|}
\hline \multirow[t]{2}{*}{ SLD } & \multicolumn{2}{|c|}{$\begin{array}{l}\text { Slope and } \\
\text { open sea }\end{array}$} & \multicolumn{2}{|c|}{$\begin{array}{c}\text { Coast and } \\
\text { continental shelf }\end{array}$} & \multirow[t]{2}{*}{$\mathrm{n}$ range } & \multirow[t]{2}{*}{$\begin{array}{l}\% \mathrm{n} \\
\text { range }\end{array}$} \\
\hline & LR & UR & LR & UR & & \\
\hline 0 & 0.00 & 3.58 & 0.00 & 4.48 & 49 & 100.0 \\
\hline 5 & 0.00 & 3.48 & 0.00 & 4.25 & 104 & 79.4 \\
\hline 10 & 0.00 & 3.31 & 0.00 & 4.12 & 48 & 96.0 \\
\hline 20 & 0.00 & 3.31 & 0.00 & 4.09 & 101 & 80.8 \\
\hline 30 & 0.00 & 3.70 & 0.00 & 4.50 & 71 & 93.4 \\
\hline 40 & 0.00 & 4.36 & 0.00 & 5.25 & 122 & 79.7 \\
\hline 50 & 0.00 & 3.94 & 0.00 & 4.78 & 40 & 97.6 \\
\hline 60 & 0.00 & 4.91 & 0.00 & 5.81 & 104 & 81.3 \\
\hline 80 & 0.00 & 5.48 & 0.00 & 6.51 & 146 & 82.5 \\
\hline 100 & 0.00 & 5.99 & 0.00 & 7.01 & 122 & 72.2 \\
\hline 120 & 0.80 & 5.78 & 0.00 & 7.03 & 19 & 65.5 \\
\hline 160 & 1.69 & 6.17 & 0.57 & 7.30 & 59 & 72.8 \\
\hline 200 & 2.41 & 6.70 & 1.34 & 7.78 & 77 & 59.7 \\
\hline 250 & 3.69 & 7.24 & & & 21 & 60.0 \\
\hline 300 & 4.80 & 9.06 & & & 57 & 59.4 \\
\hline 400 & 6.56 & 9.49 & & & 84 & 74.3 \\
\hline 500 & 7.68 & 9.27 & & & 44 & 51.2 \\
\hline 600 & 7.55 & 9.15 & & & 17 & 40.5 \\
\hline 800 & 8.29 & 9.10 & & & 27 & 51.9 \\
\hline 1000 & 8.17 & 8.92 & & & 28 & 43.8 \\
\hline 1200 & 8.32 & 8.85 & & & 12 & 75.0 \\
\hline 1400 & 8.10 & 8.69 & & & 5 & 62.5 \\
\hline 1600 & 8.00 & 8.82 & & & 9 & 40.9 \\
\hline 1800 & & & & & & \\
\hline 2000 & 8.01 & 8.93 & & & 4 & 36.4 \\
\hline 2500 & 7.96 & 9.14 & & & 4 & 66.7 \\
\hline$\geq 500$ & 7.90 & 9.13 & & & 150 & 48.4 \\
\hline Total & & & & & 1374 & 72.6 \\
\hline
\end{tabular}

TABLE 11. - Nitrite concentration $(\mu \mathrm{M})$ ranges in the NW Mediterranean Sea in mixed water columns (stratification coefficient $=1$ ). Headers as in Table 7.

\begin{tabular}{|c|c|c|c|c|c|c|}
\hline \multirow[t]{2}{*}{ SLD } & \multicolumn{2}{|c|}{$\begin{array}{l}\text { Slope and } \\
\text { open sea }\end{array}$} & \multicolumn{2}{|c|}{$\begin{array}{l}\text { Coast and } \\
\text { continental shelf }\end{array}$} & \multirow[t]{2}{*}{$\mathrm{n}$ range } & \multirow[t]{2}{*}{$\begin{array}{l}\% \mathrm{n} \\
\text { range }\end{array}$} \\
\hline & LR & UR & LR & UR & & \\
\hline 0 & 0.00 & 0.38 & 0.00 & 0.47 & 45 & 91.8 \\
\hline 5 & 0.00 & 0.31 & 0.00 & 0.38 & 137 & 95.8 \\
\hline 10 & 0.00 & 0.50 & 0.00 & 0.62 & 48 & 100.0 \\
\hline 20 & 0.00 & 0.46 & 0.00 & 0.56 & 116 & 93.5 \\
\hline 30 & 0.00 & 0.46 & 0.00 & 0.56 & 62 & 84.9 \\
\hline 40 & 0.00 & 0.45 & 0.00 & 0.53 & 129 & 83.8 \\
\hline 50 & 0.00 & 0.59 & 0.00 & 0.69 & 34 & 82.9 \\
\hline 60 & 0.00 & 0.51 & 0.00 & 0.61 & 101 & 84.9 \\
\hline 80 & 0.00 & 0.38 & 0.00 & 0.45 & 127 & 73.0 \\
\hline 100 & 0.00 & 0.36 & 0.00 & 0.43 & 140 & 82.8 \\
\hline 120 & 0.00 & 0.33 & 0.00 & 0.42 & 30 & 90.9 \\
\hline 160 & 0.00 & 0.26 & 0.00 & 0.33 & 85 & 94.4 \\
\hline 200 & 0.00 & 0.28 & 0.00 & 0.37 & 99 & 78.0 \\
\hline 250 & 0.00 & 0.11 & & & 42 & 87.5 \\
\hline 300 & 0.00 & 0.10 & & & 90 & 87.4 \\
\hline 400 & 0.00 & 0.07 & & & 95 & 79.8 \\
\hline 500 & 0.00 & 0.08 & & & 87 & 87.9 \\
\hline 600 & 0.00 & 0.07 & & & 39 & 79.6 \\
\hline 800 & 0.00 & 0.07 & & & 49 & 83.1 \\
\hline 1000 & 0.00 & 0.06 & & & 54 & 84.4 \\
\hline 1200 & 0.00 & 0.03 & & & 16 & 100.0 \\
\hline 1400 & 0.00 & 0.05 & & & 5 & 100.0 \\
\hline 1600 & 0.00 & 0.05 & & & 17 & 77.3 \\
\hline 1800 & 0.00 & 0.07 & & & 3 & 75.0 \\
\hline 2000 & 0.00 & 0.06 & & & 9 & 81.8 \\
\hline 2500 & 0.00 & 0.05 & & & 4 & 66.7 \\
\hline$\geq 500$ & 0.00 & 0.06 & & & 271 & 80.9 \\
\hline Total & & & & & 1663 & 85.3 \\
\hline
\end{tabular}

TABLE 10. - Nitrite concentration $(\mu \mathrm{M})$ ranges in the NW Mediterranean Sea in stratified water columns (stratification coefficient $=2$, 3 and 4). Headers as in Table 7.

\begin{tabular}{|c|c|c|c|c|c|c|}
\hline \multirow[t]{2}{*}{ SLD } & \multicolumn{2}{|c|}{$\begin{array}{l}\text { Slope and } \\
\text { open sea }\end{array}$} & \multicolumn{2}{|c|}{$\begin{array}{c}\text { Coast and } \\
\text { continental shelf }\end{array}$} & \multirow[t]{2}{*}{$n$ range } & \multirow[t]{2}{*}{$\begin{array}{l}\% \mathrm{n} \\
\text { range }\end{array}$} \\
\hline & LR & UR & LR & UR & & \\
\hline 0 & 0.00 & 0.19 & 0.00 & 0.25 & 370 & 96.6 \\
\hline 5 & 0.00 & 0.22 & 0.00 & 0.27 & 591 & 94.6 \\
\hline 10 & 0.00 & 0.18 & 0.00 & 0.23 & 359 & 96.8 \\
\hline 20 & 0.00 & 0.21 & 0.00 & 0.26 & 576 & 93.2 \\
\hline 30 & 0.00 & 0.23 & 0.00 & 0.29 & 628 & 94.4 \\
\hline 40 & 0.00 & 0.30 & 0.00 & 0.37 & 639 & 95.8 \\
\hline 50 & 0.00 & 0.42 & 0.00 & 0.53 & 653 & 97.3 \\
\hline 60 & 0.00 & 0.47 & 0.00 & 0.59 & 575 & 96.5 \\
\hline 80 & 0.00 & 0.42 & 0.00 & 0.52 & 1210 & 93.9 \\
\hline 100 & 0.00 & 0.31 & 0.00 & 0.38 & 1039 & 93.6 \\
\hline 120 & 0.00 & 0.21 & 0.00 & 0.28 & 399 & 95.2 \\
\hline 160 & 0.00 & 0.16 & 0.00 & 0.21 & 475 & 94.2 \\
\hline 200 & 0.00 & 0.16 & 0.00 & 0.21 & 605 & 89.4 \\
\hline 250 & 0.00 & 0.09 & & & 246 & 89.1 \\
\hline 300 & 0.00 & 0.09 & & & 376 & 83.0 \\
\hline 400 & 0.00 & 0.09 & & & 443 & 87.5 \\
\hline 500 & 0.00 & 0.10 & & & 337 & 78.4 \\
\hline 600 & 0.00 & 0.08 & & & 230 & 79.0 \\
\hline 800 & 0.00 & 0.08 & & & 243 & 77.4 \\
\hline 1000 & 0.00 & 0.08 & & & 183 & 71.8 \\
\hline 1200 & 0.00 & 0.08 & & & 42 & 80.8 \\
\hline 1400 & 0.00 & 0.09 & & & 22 & 66.7 \\
\hline 1600 & 0.00 & 0.08 & & & 60 & 73.2 \\
\hline 1800 & 0.00 & 0.07 & & & 17 & 65.4 \\
\hline 2000 & 0.00 & 0.08 & & & 40 & 90.9 \\
\hline 2500 & 0.00 & 0.07 & & & 16 & 84.2 \\
\hline$\geq 500$ & 0.00 & 0.08 & & & 1164 & 75.3 \\
\hline Total & & & & & 10374 & 91.2 \\
\hline
\end{tabular}

Nitrite surface concentration ranges at open sea stratified stations, between 0 and $30 \mathrm{~m}$ depth, were between 0.0 and $0.2 \mu \mathrm{M}$ (Table 10). There was a maximum of nitrite concentration between 60 and $80 \mathrm{~m}$ depth with a range of concentration of 0.0 to $0.5 \mu \mathrm{M}$. Below $250 \mathrm{~m}$ depth the concentration range was constant, from 0.0 to less than $0.1 \mu \mathrm{M}$. In coastal and continental shelf areas the surface concentration ranged from 0.0 to $0.3 \mu \mathrm{M}$ and the maximum upper limit was $0.6 \mu \mathrm{M}$ (Table 10).

In mixed water columns, open ocean surface nitrite concentration ranges were between 0.0 and $0.4-0.5 \mu \mathrm{M}$ (Table 11). The maximum concentration was located at $50 \mathrm{~m}$ depth, where the upper limit range reached $0.6 \mu \mathrm{M}$. The deep nitrite concentration range was the same as during the rest of the year, from 0.0 to less than $0.1 \mu \mathrm{M}$. At coastal and continental shelf stations, the surface ranges increased up to $0.4-0.5 \mu \mathrm{M}$, and the maximum upper limit concentration was $0.7 \mu \mathrm{M}$.

Nitrite data above the ranges from stations on the continental shelf were situated mainly in front of the Ebro Delta and in front of the cities of Barcelona and Palma (Fig. 1). At open sea stations, data above the ranges were observed at stations located on submarine canyons.

At open sea stratified stations, ammonium concentration ranges from the surface to $30 \mathrm{~m}$ depth were between 0 and 0.8-1.0 $\mu \mathrm{M}$ (Table 12). Below 30 to 100 $\mathrm{m}$ depth the ranges became narrower, from 0.0 to 0.5 
TABLE 12. - Ammonium concentration $(\mu \mathrm{M})$ ranges in the NW Mediterranean Sea in stratified water columns (stratification coefficient $=2,3$ and 4). Below $500 \mathrm{~m}$ depth, data was gathered only from stations with stratification index 2 , so they could not be representative for other stratification conditions. Headers as in Table 7.

\begin{tabular}{|c|c|c|c|c|c|c|}
\hline \multirow[t]{2}{*}{ SLD } & \multicolumn{2}{|c|}{$\begin{array}{l}\text { Slope and } \\
\text { open sea }\end{array}$} & \multicolumn{2}{|c|}{$\begin{array}{c}\text { Coast and } \\
\text { continental shelf }\end{array}$} & \multirow[t]{2}{*}{$\mathrm{n}$ range } & \multirow[t]{2}{*}{$\begin{array}{l}\% \mathrm{n} \\
\text { range }\end{array}$} \\
\hline & LR & UR & LR & UR & & \\
\hline 0 & 0.00 & 0.81 & 0.00 & 1.00 & 101 & 73.7 \\
\hline 5 & 0.00 & 0.51 & 0.00 & 0.63 & 61 & 100.0 \\
\hline 10 & 0.00 & 1.00 & 0.00 & 1.23 & 114 & 82.6 \\
\hline 20 & 0.00 & 0.88 & 0.00 & 1.08 & 107 & 77.5 \\
\hline 30 & 0.00 & 0.95 & 0.00 & 1.16 & 116 & 79.5 \\
\hline 40 & 0.00 & 0.79 & 0.00 & 0.97 & 100 & 65.4 \\
\hline 50 & 0.00 & 0.72 & 0.00 & 0.88 & 142 & 75.5 \\
\hline 60 & 0.00 & 0.67 & 0.00 & 0.83 & 139 & 73.2 \\
\hline 80 & 0.00 & 0.69 & 0.00 & 0.84 & 250 & 72.9 \\
\hline 100 & 0.00 & 0.70 & 0.00 & 0.87 & 181 & 74.8 \\
\hline 120 & 0.00 & 0.52 & 0.00 & 0.68 & 79 & 73.8 \\
\hline 160 & 0.00 & 0.50 & 0.00 & 0.66 & 59 & 80.8 \\
\hline 200 & 0.00 & 0.63 & 0.00 & 0.81 & 69 & 64.5 \\
\hline 250 & 0.00 & 1.01 & & & 21 & 100.0 \\
\hline 300 & 0.00 & 1.07 & & & 38 & 70.4 \\
\hline 400 & 0.00 & 0.92 & & & 46 & 85.2 \\
\hline 500 & 0.04 & 1.09 & & & 29 & 64.4 \\
\hline 600 & 0.00 & 1.36 & & & 6 & 100.0 \\
\hline 800 & 0.00 & 1.19 & & & 12 & 92.3 \\
\hline 1000 & 0.04 & 1.13 & & & 13 & 100.0 \\
\hline 1200 & & & & & & \\
\hline 1400 & 0.00 & 1.40 & & & 5 & 100.0 \\
\hline 1600 & 0.00 & 1.34 & & & 7 & 100.0 \\
\hline 1800 & 0.87 & 1.06 & & & 2 & 100.0 \\
\hline 2000 & & & & & 1 & 100.0 \\
\hline 2500 & & & & & & \\
\hline Total & & & & & 1698 & 75.7 \\
\hline
\end{tabular}

$\mu \mathrm{M}$. From 250 to $500 \mathrm{~m}$ depth ammonium concentration ranges became wider again, and below $500 \mathrm{~m}$ the concentrations ranged from 0.0 to $1.0-1.4 \mu \mathrm{M}$. At coastal and continental shelf stations, surface concentrations ranged from 0.0 to $1.0-1.2 \mu \mathrm{M}$. From 40 to 200 $\mathrm{m}$ depth, the upper limit range decreased to $0.6 \mu \mathrm{M}$.

In mixed water columns, the ammonium surface concentration ranges were more variable, and ran from $0.0-0.1 \mu \mathrm{M}$ to $1.0-2.0 \mu \mathrm{M}$ (Table 13). Ammonium concentration in mixed water columns for coastal and continental shelf stations ranged from 0.0 to 1.1-1.2 $\mu \mathrm{M}$ in surface waters and up to $2.5-2.9 \mu \mathrm{M}$ between 30 and $80 \mathrm{~m}$ depth.

High ammonium concentrations in deep waters are unexpected in an oxic environment like the NW Mediterranean Sea, and the origin of such high values remains unclear. Also, the low ammonium data makes it difficult to extrapolate, from the ranges of concentration, any feature in the vertical distribution of ammonium. Ammonium data above the ranges were located mainly in the upper $200 \mathrm{~m}$ depth, and were spread over the continental shelf. At the open sea, data above the ranges were also highly scattered.

Surface (30-40 m depth) silicate concentrations at open-sea stratified stations of the NW Mediterranean Sea ranged from 0.0 to $2.5 \mu \mathrm{M}$ (Table 14). From surface, silicate concentration ranges steadily increased to reach values of between 7.7 and $10.4 \mu \mathrm{M}$ below 1400
TABle 13. - Ammonium concentration $(\mu \mathrm{M})$ ranges in the NW Mediterranean Sea in mixed water columns (stratification coefficient $=1$ ). Headers as in Table 7 .

\begin{tabular}{|c|c|c|c|c|c|c|}
\hline \multirow[t]{2}{*}{ SLD } & \multicolumn{2}{|c|}{$\begin{array}{l}\text { Slope and } \\
\text { open sea }\end{array}$} & \multicolumn{2}{|c|}{$\begin{array}{c}\text { Coast and } \\
\text { continental shelf }\end{array}$} & \multirow[t]{2}{*}{$\mathrm{n}$ range } & \multirow[t]{2}{*}{$\begin{array}{l}\% \mathrm{n} \\
\text { range }\end{array}$} \\
\hline & LR & UR & LR & UR & & \\
\hline 0 & 0.02 & 1.22 & 0.00 & 1.51 & 12 & 92.3 \\
\hline \multicolumn{7}{|l|}{5} \\
\hline 10 & 0.04 & 1.11 & 0.00 & 1.37 & 13 & 86.7 \\
\hline 20 & 0.15 & 1.30 & 0.00 & 1.59 & 14 & 93.3 \\
\hline 30 & 0.00 & 2.03 & 0.00 & 2.56 & 14 & 100.0 \\
\hline 40 & 0.05 & 2.05 & 0.00 & 2.55 & 13 & 86.7 \\
\hline 50 & 0.04 & 2.05 & 0.00 & 2.55 & 16 & 100.0 \\
\hline 60 & 0.00 & 2.18 & 0.00 & 2.82 & 11 & 91.7 \\
\hline 80 & 0.00 & 1.94 & 0.00 & 2.45 & 19 & 95.0 \\
\hline 100 & 0.00 & 2.17 & 0.00 & 2.75 & 16 & 94.1 \\
\hline 120 & 0.42 & 1.39 & 0.00 & 1.88 & 11 & 91.7 \\
\hline 160 & 0.53 & 1.18 & 0.00 & 1.50 & 4 & 80.0 \\
\hline 200 & 0.26 & 1.24 & 0.00 & 1.74 & 12 & 85.7 \\
\hline \multicolumn{7}{|l|}{250} \\
\hline 300 & 0.71 & 1.77 & & & 4 & 80.0 \\
\hline 400 & 0.21 & 1.43 & & & 10 & 100.0 \\
\hline 500 & 0.70 & 1.61 & & & 3 & 100.0 \\
\hline \multicolumn{7}{|l|}{600} \\
\hline \multicolumn{7}{|l|}{800} \\
\hline \multicolumn{7}{|l|}{1000} \\
\hline \multicolumn{7}{|l|}{1200} \\
\hline \multicolumn{7}{|l|}{1400} \\
\hline \multicolumn{7}{|l|}{1600} \\
\hline \multicolumn{7}{|l|}{1800} \\
\hline \multicolumn{7}{|l|}{2000} \\
\hline \multicolumn{7}{|l|}{2500} \\
\hline Total & & & & & 172 & 92.5 \\
\hline
\end{tabular}

TABLE 14. - Silicate concentration $(\mu \mathrm{M})$ ranges in the NW Mediterranean Sea in stratified water columns (stratification coefficient $=2$, 3 and 4). Headers as in Table 7.

\begin{tabular}{|c|c|c|c|c|c|c|}
\hline \multirow[t]{2}{*}{ SLD } & \multicolumn{2}{|c|}{$\begin{array}{l}\text { Slope and } \\
\text { open sea }\end{array}$} & \multicolumn{2}{|c|}{$\begin{array}{c}\text { Coast and } \\
\text { continental shelf }\end{array}$} & \multirow[t]{2}{*}{$\mathrm{n}$ range } & \multirow[t]{2}{*}{$\begin{array}{l}\% \mathrm{n} \\
\text { range }\end{array}$} \\
\hline & $\mathrm{LR}^{1}$ & UR & LR & UR & & \\
\hline 0 & 0.00 & 2.58 & 0.00 & 3.15 & 422 & 94.6 \\
\hline 5 & 0.00 & 2.45 & 0.00 & 2.99 & 581 & 88.4 \\
\hline 10 & 0.00 & 2.59 & 0.00 & 3.17 & 435 & 94.8 \\
\hline 20 & 0.00 & 2.79 & 0.00 & 3.39 & 631 & 92.1 \\
\hline 30 & 0.00 & 2.67 & 0.00 & 3.22 & 699 & 91.4 \\
\hline 40 & 0.00 & 2.91 & 0.00 & 3.51 & 640 & 85.1 \\
\hline 50 & 0.00 & 3.37 & 0.00 & 4.06 & 731 & 94.7 \\
\hline 60 & 0.00 & 4.19 & 0.00 & 5.02 & 610 & 90.6 \\
\hline 80 & 0.00 & 4.57 & 0.00 & 5.40 & 1330 & 92.3 \\
\hline 100 & 0.16 & 5.15 & 0.00 & 5.98 & 1131 & 92.6 \\
\hline 120 & 1.43 & 5.15 & 0.59 & 5.98 & 438 & 92.6 \\
\hline 160 & 1.64 & 5.29 & 0.73 & 6.20 & 491 & 93.3 \\
\hline 200 & 2.17 & 6.03 & 1.20 & 6.99 & 680 & 87.5 \\
\hline 250 & 3.07 & 6.43 & & & 250 & 86.2 \\
\hline 300 & 4.17 & 7.36 & & & 391 & 78.2 \\
\hline 400 & 4.75 & 8.36 & & & 505 & 89.2 \\
\hline 500 & 5.75 & 9.09 & & & 395 & 84.0 \\
\hline 600 & 5.76 & 8.90 & & & 255 & 84.2 \\
\hline 800 & 6.54 & 9.49 & & & 246 & 72.6 \\
\hline 1000 & 6.48 & 10.49 & & & 218 & 80.7 \\
\hline 1200 & 7.10 & 10.65 & & & 35 & 61.4 \\
\hline 1400 & 7.43 & 10.85 & & & 24 & 63.2 \\
\hline 1600 & 7.63 & 10.47 & & & 59 & 64.1 \\
\hline 1800 & 8.04 & 10.51 & & & 23 & 74.2 \\
\hline 2000 & 7.92 & 10.01 & & & 37 & 72.5 \\
\hline 2500 & 7.87 & 10.22 & & & 19 & 90.5 \\
\hline$\geq 1400$ & 7.74 & 10.41 & & & 162 & 52.9 \\
\hline Total & & & & & 11276 & 89.0 \\
\hline
\end{tabular}


TABLE 15. - Silicate concentration $(\mu \mathrm{M})$ ranges in the NW Mediterranean Sea in mixed water columns (stratification coefficient $=1$ ). Headers as in Table 7.

\begin{tabular}{|c|c|c|c|c|c|c|}
\hline \multirow[t]{2}{*}{ SLD } & \multicolumn{2}{|c|}{$\begin{array}{l}\text { Slope and } \\
\text { open sea }\end{array}$} & \multicolumn{2}{|c|}{$\begin{array}{c}\text { Coast and } \\
\text { continental shelf }\end{array}$} & \multirow[t]{2}{*}{$\mathrm{n}$ range } & \multirow[t]{2}{*}{$\begin{array}{l}\% \mathrm{n} \\
\text { range }\end{array}$} \\
\hline & $\mathrm{LR}^{\mathrm{T}}$ & UR & LR & UR & & \\
\hline 0 & 0.00 & 4.22 & 0.00 & 5.00 & 59 & 93.7 \\
\hline 5 & 0.00 & 4.78 & 0.00 & 5.73 & 108 & 76.1 \\
\hline 10 & 0.00 & 3.99 & 0.00 & 4.72 & 60 & 95.2 \\
\hline 20 & 0.00 & 3.83 & 0.00 & 4.54 & 113 & 80.7 \\
\hline 30 & 0.00 & 5.14 & 0.00 & 6.08 & 87 & 96.7 \\
\hline 40 & 0.00 & 5.33 & 0.00 & 6.36 & 143 & 86.7 \\
\hline 50 & 0.00 & 4.24 & 0.00 & 4.96 & 48 & 84.2 \\
\hline 60 & 0.00 & 5.20 & 0.00 & 6.05 & 95 & 74.8 \\
\hline 80 & 0.00 & 5.22 & 0.00 & 6.13 & 144 & 73.8 \\
\hline 100 & 0.00 & 5.78 & 0.00 & 6.80 & 151 & 80.3 \\
\hline 120 & 0.81 & 4.86 & 0.00 & 5.87 & 37 & 84.1 \\
\hline 160 & 1.26 & 4.90 & 0.35 & 5.81 & 68 & 70.8 \\
\hline 200 & 2.77 & 5.64 & 2.05 & 6.36 & 80 & 54.4 \\
\hline 250 & 3.40 & 5.77 & & & 31 & 60.8 \\
\hline 300 & 4.34 & 6.74 & & & 48 & 42.1 \\
\hline 400 & 4.96 & 8.83 & & & 86 & 66.7 \\
\hline 500 & 5.46 & 9.19 & & & 67 & 61.5 \\
\hline 600 & 5.26 & 8.89 & & & 32 & 61.5 \\
\hline 800 & 6.91 & 8.84 & & & 27 & 41.5 \\
\hline 1000 & 6.79 & 9.09 & & & 33 & 47.8 \\
\hline 1200 & 7.54 & 9.25 & & & 2 & 10.5 \\
\hline 1400 & 7.67 & 10.27 & & & 7 & 70.0 \\
\hline 1600 & 8.36 & 10.65 & & & 11 & 44.0 \\
\hline 1800 & 8.88 & 10.73 & & & 4 & 57.1 \\
\hline 2000 & 8.20 & 11.12 & & & 6 & 42.9 \\
\hline 2500 & 8.21 & 10.89 & & & 6 & 75.0 \\
\hline$\geq 1400$ & 8.35 & 10.73 & & & 32 & 50.0 \\
\hline Total & & & & & 1553 & 70.9 \\
\hline
\end{tabular}

TABLE 16. - Dissolved oxygen $\left(\mathrm{ml} \mathrm{l}^{-1}\right)$ ranges in the NW Mediterranean Sea. Headers as in Table 7.

\begin{tabular}{|c|c|c|c|c|c|c|}
\hline \multirow[t]{2}{*}{ SLD } & \multicolumn{2}{|c|}{$\begin{array}{l}\text { Slope and } \\
\text { open sea }\end{array}$} & \multicolumn{2}{|c|}{$\begin{array}{c}\text { Coast and } \\
\text { continental shelf }\end{array}$} & \multirow[t]{2}{*}{$\mathrm{n}$ range } & \multirow[t]{2}{*}{$\begin{array}{l}\% \mathrm{n} \\
\text { range }\end{array}$} \\
\hline & LR & UR & LR & UR & & \\
\hline 0 & 4.22 & 6.63 & 3.82 & 7.03 & 532 & 96.9 \\
\hline 5 & 4.20 & 6.60 & 3.80 & 7.00 & 476 & 95.2 \\
\hline 10 & 4.50 & 6.52 & 4.16 & 6.86 & 523 & 92.1 \\
\hline 20 & 4.58 & 6.60 & 4.24 & 6.94 & 623 & 89.6 \\
\hline 30 & 4.73 & 6.77 & 4.39 & 7.11 & 710 & 92.1 \\
\hline 40 & 4.78 & 6.77 & 4.45 & 7.10 & 505 & 91.2 \\
\hline 50 & 4.68 & 6.75 & 4.33 & 7.10 & 688 & 91.6 \\
\hline 60 & 4.50 & 6.55 & 4.15 & 6.89 & 483 & 93.6 \\
\hline 80 & 4.46 & 6.23 & 4.16 & 6.53 & 1079 & 89.0 \\
\hline 100 & 4.48 & 5.99 & 4.18 & 6.27 & 999 & 91.7 \\
\hline 120 & 4.48 & 5.67 & 4.18 & 5.97 & 417 & 91.9 \\
\hline 160 & 4.32 & 5.61 & 4.00 & 5.93 & 525 & 95.1 \\
\hline 200 & 4.23 & 5.43 & 3.93 & 5.73 & 700 & 91.7 \\
\hline 250 & 4.08 & 5.34 & & & 390 & 95.4 \\
\hline 300 & 4.02 & 5.17 & & & 553 & 94.0 \\
\hline 400 & 3.92 & 5.03 & & & 565 & 94.3 \\
\hline 500 & 3.92 & 4.89 & & & 501 & 92.3 \\
\hline 600 & 3.98 & 4.93 & & & 316 & 92.1 \\
\hline 800 & 4.05 & 4.86 & & & 411 & 96.0 \\
\hline 1000 & 4.25 & 4.85 & & & 294 & 90.5 \\
\hline 1200 & 4.28 & 4.82 & & & 136 & 88.3 \\
\hline 1400 & 4.33 & 4.81 & & & 109 & 95.6 \\
\hline 1600 & 4.40 & 4.82 & & & 128 & 94.1 \\
\hline 1800 & 4.40 & 4.87 & & & 72 & 94.7 \\
\hline 2000 & 4.46 & 4.80 & & & 86 & 94.5 \\
\hline 2500 & 4.44 & 4.78 & & & 68 & 98.6 \\
\hline Total & & & & & 11889 & 92.5 \\
\hline
\end{tabular}

m. At coastal and continental shelf stations, silicate in surface waters ranged from 0.0 to $3.0-3.2 \mu \mathrm{M}$. The lower limit was $0.0 \mu \mathrm{M}$ from surface to $100 \mathrm{~m}$ depth, increasing up to $1.2 \mu \mathrm{M}$ at $200 \mathrm{~m}$ depth. The upper limit range increased steadily from the surface, reaching values of $7.0 \mu \mathrm{M}$ at $200 \mathrm{~m}$ depth.

In mixed water columns, silicate concentration ranges in the open ocean in the first $100 \mathrm{~m}$ depth were wider than the ranges at stratified stations, from 0.0 to $5.8 \mu \mathrm{M}$. From $120 \mathrm{~m}$ they increased linearly with depth to reach maximum values of 5.5-9.2 $\mu \mathrm{M}$ at 500 $\mathrm{m}$ depth (Table 15). Winter ranges in deep waters were similar to those of the rest of the year $(8.4-10.7 \mu \mathrm{M})$. For coastal and continental shelf stations, upper limit ranges were between 4.5 and $6.0 \mu \mathrm{M}$ and did not show a clear pattern. The lower limit was $0.0 \mu \mathrm{M}$ from surface waters to $120 \mathrm{~m}$ depth, increasing to $2.0 \mu \mathrm{M}$ at $200 \mathrm{~m}$ depth.

Silicate data above the described concentration ranges were located in front of the Ebro Delta and in front of the city of Palma, both on the continental shelf and slope. In the open sea area, values below the range were mostly found inside submarine canyons.

Open sea surface dissolved oxygen concentration ranges in the NW Mediterranean Sea were between 4.2 and $6.6 \mathrm{ml} \mathrm{l}^{-1}$ (Table 16). Dissolved oxygen concentration increased with depth up to $40 \mathrm{~m}$, where the concentration range was 4.8 to $6.8 \mathrm{ml} \mathrm{l}^{-1}$. Below this depth, the ranges decreased to 400-500 $\mathrm{m}$ depth, where a lower limit of $3.9 \mathrm{ml} \mathrm{l}^{-1}$ was found. Finally, from 500

TABLE 17. - Chl $a$ concentration $\left(\mu \mathrm{g}^{-1}\right)$ ranges in the NW Mediterranean Sea in stratified water columns ( stratification coefficient $=2$, 3 and 4). Headers as in Table 7.

\begin{tabular}{|c|c|c|c|c|c|c|}
\hline \multirow[t]{2}{*}{ SLD } & \multicolumn{2}{|c|}{$\begin{array}{l}\text { Slope and } \\
\text { open sea }\end{array}$} & \multicolumn{2}{|c|}{$\begin{array}{c}\text { Coast and } \\
\text { continental shelf }\end{array}$} & \multirow[t]{2}{*}{$\mathrm{n}$ range } & \multirow[t]{2}{*}{$\begin{array}{l}\% \mathrm{n} \\
\text { range }\end{array}$} \\
\hline & LR & UR & LR & UR & & \\
\hline 0 & 0.00 & 0.83 & 0.00 & 1.03 & 385 & 90.8 \\
\hline 5 & 0.00 & 1.05 & 0.00 & 1.31 & 294 & 88.6 \\
\hline 10 & 0.00 & 1.08 & 0.00 & 1.36 & 331 & 94.3 \\
\hline 20 & 0.00 & 1.74 & 0.00 & 2.17 & 414 & 96.1 \\
\hline 30 & 0.00 & 1.36 & 0.00 & 1.71 & 520 & 97.2 \\
\hline 40 & 0.00 & 1.78 & 0.00 & 2.19 & 478 & 94.8 \\
\hline 50 & 0.00 & 1.70 & 0.00 & 2.09 & 508 & 93.7 \\
\hline 60 & 0.00 & 1.70 & 0.00 & 2.07 & 429 & 94.7 \\
\hline 80 & 0.00 & 1.29 & 0.00 & 1.57 & 932 & 92.5 \\
\hline 100 & 0.00 & 0.92 & 0.00 & 1.13 & 688 & 83.2 \\
\hline 120 & 0.00 & 0.35 & 0.00 & 0.45 & 242 & 96.4 \\
\hline 160 & 0.00 & 0.26 & 0.00 & 0.35 & 234 & 94.4 \\
\hline 200 & 0.00 & 0.16 & 0.00 & 0.21 & 271 & 91.2 \\
\hline 250 & 0.00 & 0.18 & & & 53 & 86.9 \\
\hline 300 & 0.00 & 0.10 & & & 39 & 73.6 \\
\hline 400 & 0.00 & 0.05 & & & 67 & 91.8 \\
\hline 500 & 0.00 & 0.05 & & & 24 & 77.4 \\
\hline 600 & 0.00 & 0.05 & & & 10 & 83.3 \\
\hline 800 & 0.00 & 0.05 & & & 5 & 62.5 \\
\hline 1000 & 0.00 & 0.03 & & & 5 & 45.5 \\
\hline 1200 & 0.00 & 0.00 & & & 1 & 100.0 \\
\hline 1400 & & & & & & \\
\hline 1600 & 0.00 & 0.00 & & & 1 & 100.0 \\
\hline 1800 & & & & & & \\
\hline 2000 & & & & & & \\
\hline 2500 & & & & & & \\
\hline Total & & & & & 5931 & 91.9 \\
\hline
\end{tabular}


TABLE 18. - Chl $a$ concentration $\left(\mu \mathrm{g} \mathrm{l}^{-1}\right)$ ranges in the NW Mediterranean Sea in mixed water columns (stratification coefficient $=1$ ). Headers as in Table 7.

\begin{tabular}{|c|c|c|c|c|c|c|}
\hline \multirow[t]{2}{*}{ SLD } & \multicolumn{2}{|c|}{$\begin{array}{l}\text { Slope and } \\
\text { open sea }\end{array}$} & \multicolumn{2}{|c|}{$\begin{array}{l}\text { Coast and } \\
\text { continental shelf }\end{array}$} & \multirow[t]{2}{*}{$\mathrm{n}$ range } & \multirow[t]{2}{*}{$\begin{array}{l}\% \mathrm{n} \\
\text { range }\end{array}$} \\
\hline & LR & UR & LR & UR & & \\
\hline 0 & 0.00 & 2.01 & 0.00 & 2.31 & 41 & 66.1 \\
\hline 5 & 0.00 & 1.78 & 0.00 & 2.12 & 91 & 77.8 \\
\hline 10 & 0.00 & 2.15 & 0.00 & 2.53 & 54 & 79.4 \\
\hline 20 & 0.00 & 2.29 & 0.00 & 2.73 & 110 & 85.3 \\
\hline 30 & 0.00 & 2.14 & 0.00 & 2.56 & 69 & 81.2 \\
\hline 40 & 0.00 & 2.06 & 0.00 & 2.46 & 128 & 82.1 \\
\hline 50 & 0.00 & 2.20 & 0.00 & 2.60 & 49 & 81.7 \\
\hline 60 & 0.00 & 1.10 & 0.00 & 1.31 & 78 & 70.3 \\
\hline 80 & 0.00 & 0.99 & 0.00 & 1.18 & 125 & 71.0 \\
\hline 100 & 0.00 & 0.77 & 0.00 & 0.92 & 106 & 69.7 \\
\hline 120 & 0.00 & 0.42 & 0.00 & 0.53 & 20 & 60.6 \\
\hline 160 & 0.00 & 0.39 & 0.00 & 0.51 & 61 & 84.7 \\
\hline 200 & 0.00 & 0.41 & 0.00 & 0.53 & 78 & 83.9 \\
\hline 250 & 0.00 & 0.31 & & & 21 & 84.0 \\
\hline 300 & 0.00 & 0.21 & & & 17 & 60.7 \\
\hline 400 & 0.00 & 0.06 & & & 17 & 89.5 \\
\hline 500 & 0.00 & 0.10 & & & 7 & 70.0 \\
\hline 600 & 0.00 & 0.05 & & & 6 & 75.0 \\
\hline 800 & & & & & 0 & 0.0 \\
\hline 1000 & & & & & 0 & 0.0 \\
\hline 1200 & & & & & & \\
\hline 1400 & & & & & & \\
\hline 1600 & & & & & & \\
\hline 1800 & & & & & & \\
\hline 2000 & & & & & & \\
\hline 2500 & & & & & 0 & 0.0 \\
\hline Total & & & & & 1078 & 76.6 \\
\hline
\end{tabular}

$\mathrm{m}$ to the bottom, concentration increased slightly with depth to reach values of 4.4-4.8 $\mathrm{ml} \mathrm{l}^{-1}$. Concentration ranges at coastal and continental shelf stations were from 4.2-7.0 $\mathrm{ml} \mathrm{l}^{-1}$ in surface waters to $3.9-5.7 \mathrm{ml} \mathrm{l}^{-1}$ at $200 \mathrm{~m}$ depth. The maximum upper limit found was 7.1 $\mathrm{ml} \mathrm{l}^{-1}$. This value is close to the upper limit proposed in the MEDATLAS database (7.0 $\mathrm{ml} \mathrm{l}^{-1}$, Medar Group, 2002). The few dissolved oxygen data above the ranges encountered on the continental shelf were located in front of the Ebro Delta and the city of Barcelona.

Surface chl $a$ concentration ranges in open sea stratified waters from the NW Mediterranean Sea were around 0.0 and $1.0 \mu \mathrm{g} \mathrm{l}^{-1}$ (Table 17). The lower limit was $0.0 \mu \mathrm{g} \mathrm{l}^{-1}$ for all the SLDs. The maximum values were found between 40 and $60 \mathrm{~m}$ depth (the usual depth of the DCM in the NW Mediterranean Sea), where the upper limit concentration ranges were 1.7-1.8 $\mu \mathrm{g} \mathrm{l}^{-1}$. Below $200 \mathrm{~m}$, the observed chl $a$ concentration range was between 0.0 and $0.05 \mu \mathrm{g} \mathrm{l}^{-1}$, although there were very few available data. At coastal and continental shelf stations, the upper limit of the surface concentration ranges increased from 1.0 to 1.7-2.2 $\mu \mathrm{g} \mathrm{l}^{-1}$ at the DCM. Below this, the upper limit decreased with depth to reach $0.21 \mu \mathrm{g} \mathrm{l}^{-1}$ at $200 \mathrm{~m}$.

In mixed water columns, the chl $a$ concentration ranges in surface open seawaters rose to $2.3 \mu \mathrm{g} \mathrm{l}^{-1}$ (Table 18). The concentration then decreased steadily with depth from 20 to $120 \mathrm{~m}$, where values were $0.0-0.4 \mu \mathrm{g}$ $\mathrm{l}^{-1}$. In deep waters, concentration ranges were similar to those described for the rest of the year. At coastal and continental shelf stations, the winter upper limit for chl $a$ concentration ranges was higher than $2.0 \mu \mathrm{g}$ $\mathrm{l}^{-1}$ from surface waters to $50 \mathrm{~m}$ depth. The maximum value found was $2.7 \mu \mathrm{g} \mathrm{l}^{-1}$. At $200 \mathrm{~m}$ depth, the chl $a$ upper limit range was $0.5 \mu \mathrm{g} \mathrm{l}^{-1}$. The highest chl $a$ concentrations were found in front of the Ebro Delta, in front of the cities of Barcelona and Palma and inside some submarine canyons.

The proportion of data within the quality control ranges for each variable from the cruises gathered, as well as from the historical databases, is shown in Table 19 , which also shows the proportions of data outside the ranges from open sea versus coast and continental shelf stations, and from preserved samples versus samples analyzed on board.

Using the data included within the QC ranges of concentration described in the present paper, vertical profiles for the different oceanographic variables have been obtained and are described elsewhere (SeguraNoguera et al., submitted).

\section{DISCUSSION}

\section{Analytical precision}

It would be desirable for all the analytical data reported elsewhere to also incorporate information about some basic parameters, such as the limit of detection and the analysis precision. This was not the case with most of the data gathered, so we estimated the analytical precision using different methodologies, according to the data available for each cruise.

Our results indicate that standard deviations estimated following Garcia et al. (1998) were usually higher than those calculated from repeated analyses

TABLE 19. - Proportion (\%) of the data gathered that is found within and outside the quality control ranges defined in this study.

\begin{tabular}{|c|c|c|c|c|c|c|}
\hline & \multicolumn{2}{|c|}{ Within the QC Ranges } & \multicolumn{2}{|c|}{ Outside the QC Ranges } & \multirow[b]{2}{*}{$\begin{array}{c}\text { Samples analyzed } \\
\text { on board }\end{array}$} & \multirow[b]{2}{*}{ Frozen samples } \\
\hline & Cruises & Databases & Open Sea and Slope & $\begin{array}{l}\text { Coast and } \\
\text { Cont. Shelf }\end{array}$ & & \\
\hline Phosphate & 91.9 & 93.4 & 7.0 & 1.1 & 9.8 & 8.0 \\
\hline Nitrate & 90.8 & 84.4 & 8.6 & 0.6 & 7.6 & 22.7 \\
\hline Nitrite & 91.4 & 97.1 & 7.1 & 1.4 & 11.9 & 6.4 \\
\hline Ammonium & 73.5 & 57.2 & 17.1 & 9.3 & 17.1 & 34.6 \\
\hline Silicate & 94.4 & 96.4 & 5.2 & 0.4 & 5.2 & 10.8 \\
\hline Dissolved oxygen & 95.2 & 94.9 & 4.6 & 0.2 & & \\
\hline Chlorophyll $a$ & 94.5 & 96.2 & 5.3 & 6.0 & & \\
\hline
\end{tabular}


of the same sample or from standards, because they included a component of natural variability. This component was even more evident when we compared the precision estimated using data in the different water masses: better precision values were obtained using data in the WMDW, which is the most stable water mass, physically and chemically. Worse values were obtained using data from the core of the LIW or using all data sampled in LIW. This is because this water type (the core of the LIW) and water mass (the whole LIW) can be present in the NW Mediterranean Sea under different degrees of modification after its formation in the eastern Mediterranean Sea or other areas of the Mediterranean Sea (Emelianov et al., 2006); it is physically less stable than WMDW. Furthermore, at the interval of $200-600 \mathrm{~m}$ depth where the LIW is detected, the remineralization and dissolution processes are still active, so nutrient and dissolved oxygen concentrations are not constant. Thus, if the precision must be estimated following Garcia et al. (1998), we recommend using data from WMDW but not from the other water masses of the NW Mediterranean Sea.

Better precisions were obtained with the other methods used to estimate the analytical precision ( $\mathrm{Ta}$ ble 3). Again, a component of natural variability can be observed when the precision is calculated from different bottles of the same water mass, rather than when it is calculated from different samples from the same Niskin bottle, as can be observed in the "Varimed 95" cruise (Table 3). Another factor that could have an influence on the variation of the estimated analytical precision is the analyst (Hager et al., 1972).

Finally, traceability is another chemical parameter that should be taken into account in studies about the quality of the data. Even if the precision and the limit of detection of an analysis are acceptable, a systematic error can be present (e.g. by using a contaminated baseline or reagents). In this case, all the analyses will be deviated from the real value in the same way. The standards from which the calibration line is calculated are the most important source of systematic errors in nutrient analysis (Gordon et al., 1993). The best way to know whether the results obtained are true is to use certified reference material (Riu et al., 2002), but the participation in intercalibration experiments also gives an idea of how exact the laboratory analyses are. The only traceable nutrient values are those provided by the Department of Aquatic Biogeochemistry (CEAB-CSIC, analysts 2 and 3 in Appendix 2), which participated in an interlaboratory experiment and demonstrated a high accuracy in the analysis (Aminot and Kirkwood, 1995).

\section{Nutrient preservation}

According to Chapman and Mostert (1990), freezing is a suitable method for nutrient preservation if the study can support errors as high as $10 \%$, for example, in studies dealing with anthropogenic contamination.
However, for open deep sea water studies that require higher precision or studies of nutrient limitation in euphotic layers where concentrations are low, nutrient analyses should be done immediately.

Our laboratory experiment results indicate that freezing is a valid preservation method that did not significantly affect the concentration of phosphate, nitrate and silicate in samples coming from historical cruises in the NW Mediterranean Sea. The analysis errors calculated for preserved samples are $6.3 \%$ for phosphate, $1.6 \%$ for nitrate and $2.5 \%$ for silicate. These results are consistent with the results from the comparison of preserved and unpreserved nutrient samples from cruises in the NW Mediterranean Sea and with those from studies performed at other locations (Stéfansson and Richards, 1963; Strickland and Parsons, 1972; Riley et al. 1975; Chapman and Mostert, 1990; Avanzino and Kennedy, 1993; Valderrama, 1995; Dore et al., 1996; Krom et al., 2005).

By contrast, nitrite and ammonium concentrations in samples from the NW Mediterranean Sea are significantly altered by freezing, as has been observed previously in other regions (Carpenter and McCarthy, 1975; Eppley et al., 1977). The relative errors are higher than those found for the other nutrients: $11.4 \%$ for nitrite analysis and $18.2 \%$ for ammonium analysis. However, the decrease in nitrite concentration due to freezing $(0.04 \mu \mathrm{M})$ is similar to the baseline contamination estimated from the use of ASW made with $\mathrm{NaCl}$ diluted in double-distilled water $(0.03-0.06 \mu \mathrm{M})$. Thus, it is not clear whether the different concentrations found for preserved and unpreserved nitrite samples are the consequence of both preservation procedure and differences in the nitrite concentration in ASW. It is also possible that nitrite had been quickly oxidized to nitrate during the realization of the experiment or during the handling of the cruise samples.

The increase in ammonium concentration (0.39 $\mu \mathrm{M})$ is higher than the contamination introduced by the use of ASW $(0.23-0.26 \mu \mathrm{M})$ and close to the upper limit of the precision calculated $(0.04-0.43 \mu \mathrm{M}$-this last parameter calculated for cruises on which nutrient samples were frozen, as can be observed in Table 3). It is evident that the ammonium concentration was affected by the analysis baseline used, as well as by freezing of the samples. The error in the analysis is much higher when it is calculated with data from the cruises $(102 \%$, Table 6). Moreover, the ammonium data gathered that has been frozen previous to analysis showed the highest percentage (35\%) of data outside the resulting QC ranges of concentration among the studied variables (Table 19). Thus, we do not recommend using historical ammonium data from samples that have been preserved by freezing, because both the accuracy and the precision of the analysis are significantly affected. If nutrient samples need to be frozen, it is important, both for ammonium and nitrite analyses, to establish which part of the error is due to the use of ASW and/ or distilled water as a baseline, and which is caused 
by the freezing process, including the handling of the samples. For a revision of storage, pre-treatment of the samples and the risk of contamination during analysis, it is recommended to read Aminot et al. (2009).

The results of the comparison of preserved and unpreserved samples from cruises were used only as a reference. This is because it is not realistic to assume that the precautions taken in the laboratory experiment during the sampling process and later freezing and analysis, described above, were followed in all cruises. According to Aminot and Kérouel (1998), the main disadvantage of freezing nutrient samples is that they should be continuously kept frozen until the moment of the analysis, so there is always a risk of losing the samples if the equipment fails. The transfer of the frozen samples from the ship to the laboratory on land is particularly critical, as the samples can be partially melted down if transfer takes too long. It was not possible to check whether this has happened during the manipulation of preserved samples on any of the cruises of this study.

Usually during a cruise on which the samples were analyzed on board, some samples had to be preserved when there were malfunctions of the autoanalyzer, or when it was not possible to work because of the bad weather. Therefore, it is likely that not all the samples that we treated as analyzed on board should be in that group. It was thus predictable that the resulting concentration errors would be higher than those calculated in the laboratory experiment, as in fact happened. As a consequence, the errors shown in Table 6 can be considered as the highest ones that can be obtained when nutrient samples are frozen during the course of an oceanographic cruise.

Part of the increase in nutrient, except nitrite, found for cruises on which the nutrients were preserved could be reflecting the proportion of cruises on which the water column was mixed (stratification index 1). The number of cruises on which samples were frozen was 4 out of 10 , but the number of those cruises on which samples were analyzed on board was only 4 out of 18 . Note that the highest surface values of all nutrients were found when the water column was mixed and that most of the samples were commonly taken in the upper $100 \mathrm{~m}$.

It is also possible that the higher mean concentrations of phosphate, nitrate and ammonium calculated in preserved samples compared with unpreserved ones-observed both in the laboratory experiment and in the comparison of cruise samples - were the result of breaking cells during the freezing process, reinforcing the hypothesis of Carpenter and McCarthy (1975).

\section{QC concentration ranges}

In this study, ranges of concentration of key oceanographic variables in the NW Mediterranean Sea are reported. The QC ranges for oceanographic data in this area were obtained following the methodology pro- posed by Conkright et al. (1994, 2000). However, one of the steps proposed by those authors was skipped. This step consisted in the interpolation of the data whose depth was not coincident with an SLD, in order to obtain the value in the SLD. This step was skipped because of the segmentation of the profiles available in the NW Mediterranean Sea, which usually only cover up to 12 of the 26 SLD considered by Fichaut $e t$ al. (1997). Moreover, the sampling was concentrated mainly in surface waters; the amount of data below 120 $m$ decreased in number with increasing depth (see Tables 9-21). It should also be taken into account that the SLDs considered by Fichaut et al. (1997) for the Mediterranean Sea and used in the present study, include more SLDs in surface waters (0-120 m depth, an area of high variation and low concentrations for most of the variables studied) than the SLDs used by Conkright et al. (1994, 2000). While the resolution in surface waters should be improved, more SLDs involve fewer data at each depth. Therefore, it was considered that the interpolation, together with the relatively low amount of data on hand compared to those gathered by Conkright et al. (1994, 2000), would result in an increase in the uncertainty instead of improving the profile.

Also, some QCs can observe false maximums and minimums at $100 \mathrm{~m}$ depth, which are the consequence of using different standard deviations to define the concentration ranges.

Seasonal variations in surface nutrient concentration and in chl $a$ concentration emerged clearly during the development of QCs, when most of the winter data except for phosphate and dissolved oxygen data were found outside the concentration ranges, as it is known that vertical mixing is related to an increase in nutrients and chl $a$ at the surface. Consequently, QCs were developed separately for those data coming from mixed water column stations (winter conditions alone) and from stratified stations. Unfortunately, these QCs for winter conditions alone should be taken with precaution because the amount of data used to establish them is sometimes very low. The scarcity of data is observed with variations in the standard deviation between consecutive SLDs, which leads to abrupt variations in the amplitude of the ranges.

Finally, due to the possible error introduced by the freezing of ammonium samples, only ammonium data from onboard analysis were used to define the QC for this nutrient in the NW Mediterranean Sea. Unfortunately, below $500 \mathrm{~m}$ depth only ammonium data from spring are available, and it is not known how representative ammonium spring concentrations of deep waters are throughout the whole year. We therefore recommend the use of the $\mathrm{QC}$ for ammonium samples only from the surface to $500 \mathrm{~m}$ depth.

\section{ACKNOWLEDGEMENTS}

This work was supported by projects CANYONS (MAR99-1060-C03, CYCIT), CACO (REN2002- 
01339/MAR, MEC), and PUDEM (REN200306637-C02), and by an I3P fellowship (CSIC, MEC) to M.S.-N. We thank Marta Estrada, Jordi Salat, Miquel Alcaraz and Laura Arin (Institut de Ciències del Mar, CSIC) for providing bibliographic data, as well as Ana Sabatés and Albert Palanques (Institut de Ciències del Mar, CSIC) for providing cruise opportunities to obtain the most recent data. We thank Mikhail Emelianov (Institut de Ciències del Mar, CSIC) and the personnel of UTM (CSIC) for useful assistance during the Canyons and Caco cruises, and Linda Lamb for the English revision of this manuscript. We also thank two anonymous reviewers for helpful comments on the manuscript.

\section{REFERENCES}

Aminot, A. and R. Kérouel. - 1998. Pasteurization as an alternative method for preservation of nitrate and nitrite in seawater samples. Mar. Chem., 61: 203-208.

Aminot, A. and D. Kirkwood. - 1995. Report on the results of the fifth ICES comparison exercise for nutrients in sea water. ICES Cooperative Research Report, 213. Copenhagen.

Aminot, A., R. Kérouel and S.C. Coverly. - 2009. Nutrients in Seawater Using Segmented Flow Analysis. In: O. Wurl (ed.), Practical Gudelines for the Analysis of Seawater. CRC Press, 143-178.

Avanzino, R.J. and V.C. Kennedy. - 1993. Long-term frozen storage of stream water samples for dissolved orthophosphate, nitrate plus nitrite, and ammonium analysis. Water Resour. Res., 29: 3357-3362.

Bendschneider, K. and R. Robinson. - 1952. A new spectrophotometric method for the determination of nitrite in sea water. $J$. Mar. Res., 11(1): 87-96.

Benesch, R. and P. Mangelsdorf. - 1972. A method for the colorimetric determination of ammonium in sea water. Helgoländer Wiss Meeresunters, 23: 265-375.

Béthoux, J.P. and G. Copin-Montégut. - 1986.Biological fixation of atmospheric nitrogen in the Mediterranean Sea. Limnol. Oceanogr., 31: 1353-1358.

Béthoux, J.P., P. Morin, C. Chaumery, O. Connan, B. Gentili and D. Ruiz-Pino. - 1998. Nutrients in the Mediterranean Sea, mass balance and statistical analysis of concentrations with respect to environmental change. Mar. Chem., 63: 155-169.

Béthoux, J.P., X. Durrieu de Madron, F. Nyffeler and D. Tailliez. 2002. Deep water in the western Mediterranean. Peculiar 1999 and 2000 characteristics, shelf formation hypothesis, variability since 1970 and geochemical inferences. J. Mar. Sys., 33-34: $117-131$.

Bower, C.E. and T. Holm-Hansen. - 1980. A salicylate-hypochlorite method for determining ammonium in seawater. Can. J. Fish. Aquat. Sci., 37:794-798.

Carpenter, E.J. and J.J. McCarthy. - 1975. Nitrogen fixation and uptake of combined nitrogenous nutrients by Oscillatoria (Trichodesmium) thiebautii in western Sargasso Sea. Limnol. Oceanogr., 20: 389-401.

Chapman, P. And S.A. Mostert. - 1990. Does freezing of nutrient samples cause analytical errors. South African J. Mar. Sci., 9: 239-247.

Conkright, M.E., T.P. Boyer, S. Levitus. - 1994. Quality control and processing of historical oceanographic nutrient data. NOAA Technical Report NESDIS 79. NOAA, Washington DC.

Conkright, M.E., H.E. Garcia, T.D. O'Brien, R.A. Locarnini, T.P Boyer and C. Stephens, J.I. Antonov. - 2000. World ocean atlas. Volume 4: Nutrients. NOAA Atlas NESDIS 52. NOAA, Washington DC

Cruzado, A. - 1989. Automatic Techniques for Seawater Analysis. Info. Tec. CEAB Ocean., 23.

Culbertson, C.H., G. Knapp, M.C. Stalcup, R.T. Williams and F. Zemlyak. - 1991. A comparison of methods for the determination of dissolved oxygen in seawater. WHP Office Report WHPO-91-2.

DeGobbis, D. - 1973. On the storage of seawater samples for am- monium determination. Limnol. Oceanogr., 18: 146-150.

Dore, J.E., T. Houlihan, D.V. Hebel, G. Tien, L. Tupas and D.M. Karl. - 1996. Freezing as a method of sample preservation for the analysis of dissolved inorganic nutrients in seawater. Mar. Chem., 53: 173-185.

Duarte, C.M., S. Agustí, H. Kennedy and D. Vaqué. - 1999. The Mediterranean climate as a template for Mediterranean marine ecosystems: the example of the northeast Spanish littoral. Prog. Oceanogr., 44: 245-270.

Emelianov, M., J. Font, A. Turiel, C. Millot, J. Solé, P.-M. Puolain, A. Julià and M.-R. Vitrià. - 2006. Transformation of Levantine Intermediate Water tracked by MEDARGO floats in the Western Mediterranean. Ocean Sci., 2: 281-290.

Eppley, R.W., J. H. Sharp, E.H. Renger, M.J. Perry and W.G. Harrison. - 1977. Nitrogen assimilation by phytoplankton and other microorganisms in surface waters of central North Pacific Ocean. Mar. Biol., 39: 111-120.

Estrada, M. - 1999. Hidrodinàmica i fitoplàncton en el Mar Català. Memorias de la Real Academia de Ciencias y Artes de Barcelona, 961. Vol. LVIII, num. 6: 189-247.

Fichaut, M., E. Balopoulos, L. Baudet, H. Dooley, M.-J. GarcíaFernández, A. Iona, D. Jourdan and C. Maillard. - 1997. A common protocol to assemble a coherent database from distributed heterogeneous data sets: the MEDATLAS database experience. Proc. MAST workshop on project data management, June 1997, Ispra, Italy.

Garcia, H., A. Cruzado, L. Gordon and J. Escanez. - 1998. Decadalscale chemical variability in the subtropical north Atlantic deduced from nutrient and oxygen data. J. Geophys. Res., 103: 2817-2830.

Gomez-Taylor, M., H.D. Kahn, W.A. Telliard, K. Ditthavong, L. Kopylev, H. McCarty, L. Riddick, K. Miller, J. Cuddeback, D. Rushneck, S. Dedah, K. Stralka. - 2003. Technical Support Document for the Assessment of Detection and Quantitation Approaches. U.S. Environmental Protection Agency, Washington D.C.

Gordon, L.I., J.C. Jennings, Jr.A.A. Ross and J.M. Krest. - 1993. A suggested protocol for continuous flow automated analysis of seawater nutrients (phosphate, nitrate, nitrite and silicic acid) in the WOCE Hydrographic Program and the Joint Global Ocean Fluxes Study. WOCE Hydrographic Program Office, Methods Manual WHPO 91-1.

Grasshoff, K. - 1964. On the determination of silica in sea water. Deep-Sea Res., 11: 597-604.

Grasshoff, K. - 1970. Technicon paper, 691: 57.

Grasshoff, K., M. Ehrhardt and K. Kremling K. - 1983. Methods of seawater analysis. Verl. Chem., Weinheim.

PEPS Group. - 1986. Datos oceanográficos básicos de las campañas PEP-82, PEP-83 y PEP-84 en el mar Catalán. Datos Informativos Instituto de Ciencias del Mar, Barcelona, 19: 1-100.

Hager, S.W., E.L. Atlas, L.I. Gordon, A.W. Mantyla and P.K. Park. -1972 . A comparison at sea of manual and autoanalyzer analyses of phosphate, nitrate and silicate. Limnol. Oceanogr., 17(6): 931-937.

Hansen, H.P. - 1999. Determination of oxygen. In: K. Grasshoff, K. Kremling and M. Ehrhardt (eds.), Methods of Seawater Analysis. Wiley-VCH, 75-89.

Hansen, H.P. and F. Koroleff. - 1999. Determination of nutrients. In: K. Grasshoff, K. Kremling and M. Ehrhardt (eds.), Methods of Seawater Analysis. Wiley-VCH, 191-228.

Kremling, K. and L. Brügmann. - 1999. Filtration and Storage. In: K. Grasshoff, K. Kremling and M. Ehrhardt (eds.), Methods of Seawater Analysis. Wiley-VCH, 27-40.

Krom, M.D., E.M.S. Woodward, B. Herut, N. Kress, P. Carbo, R.F.C. Mantoura, G. Spyres, T.F. Thingstad, P. Wassmann, C. Wexels-Riser, V. Kitidis, C.S. Law and G. Zodiatis. - 2005. Nutrient cycling in the south east levantne basin of the Eastern Mediterranean: results from a phosphorus starved system. Deep-Sea Res. II., 52: 2879-2896.

Lomas, M.W. and F. Lipschultz. - 2006. Forming the primary nitrite maximum: nitrifiers or phytoplankton? Limnol. Oceanogr., 51(5): 2453-2467.

Masó, M. and PEPS Group. - 1988. Datos oceanográficos básicos de las campañas Fronts-3-85, Fronts-6-85, PEP-86, Fronts-11-86 y PEP-87 en el mar Catalán. Datos Informativos Instituto de Ciencias del Mar, Barcelona, 24: 1-83.

Masó, M. and Varimed Group. - 1995. Datos Oceanográficos Bási- 
cos de las Campañas «FRONTS 1992» (octubre-noviembre 1992) y «Variabilidad de mesoescala en el Mediterráneo Occidental» (junio 1993). Datos Informativos Instituto de Ciencias del Mar, Barcelona, 27: 1-117.

Mater Group. - 2001. MTPII-MATER 1996-1999 (Mass transfer and ecosystem response) database. IFREMER Edition (1 CD).

Medar Group. - 2002. MEDATLAS/2002 database. Mediterranean and Black Sea database of temperature salinity and bio-chemical parameters. Climatological Atlas. IFREMER Edition (4 CD).

Millot, C. - 1999. Circulation in the western Mediterranean Sea. $J$. Mar. Sys., 20: 423-442.

Morán, X.A.G., J.M. Gasol, L. Arin and M. Estrada. A comparison between glass fiber and membrane filters for the estimation of phytoplankton POC and DOC production. Mar. Ecol. Prog. Ser., 187: 31-41.

Moutin, T. and P. Raimbault. - 2002. Primary production, carbon export and nutrients availability in Western and Eastern Mediterranean Sea in early summer 1996 (MINOS cruise). J. Mar. Sys., 33: 273-288.

Murphy, J. and J.P. Riley. - 1962. A modified single solution method for the determination of phosphate in natural waters. Anal. Chim. Acta, 27: 31-36.

Parsons, T.R., M. Takahashi and B. Hargrave. - 1984. Biological Oceanographic Processes. Pergamon Press, Oxford.

Pond, S. and G.L. Pickard. - 1983. Introductory Dynamical Oceanography. Pergamon Press, Oxford.

Riley, J.P., D.E. Robertson, J.W.R. Dutton, N.T. Mitchell and P.J.leB. Williams. - 1975. Analytical chemistry of Sea Water. In: J.P. Riley and G. Skirrow (eds.), Chemical Oceanography. Vol.3, Academic Press, 193-433.

Riu, J., A. Maroto, R. Boqué, F.X. Rius. - 2002. Determinació de la traçabilitat en mesures químiques. Notícies per a Químics, 407: 5-8.

Salat, J. - 1995. The interaction between the Catalan and Balearic currents in the southern Catalan Sea. Oceanol. Acta, 18(2): 227-234.

Salat, J. - 1996. Review of hydrographic environmental factors that may influence habitats in northwestern Mediterranean. Sci. Mar., 60(Suppl. 2): 21-32.

Salat, J. and A. Cruzado. - 1981. Masses d'eau dans la Mediterranée Occidentale: Mer Catalane et eaux adjacentes. Rapp. Comm.
Int Mer Médit. 27(6): 201-209.

Send, U., J. Font, G. Krahmann, C. Millot, M. Rhein and J. Tintore. - 1999. Recent advances in observing the physical oceanography of the western Mediterranean Sea. Progr. Oceanogr., 44: 37-64.

Stéfansson, U. and F. Richards. - 1963. Processes contributing to the nutrient distributions off the Columbia River and Strait of Juan de Fuca. Limnol. Oceanogr., 8: 394-410.

Strickland, J.D.H. and T.R. Parsons. - 1972. A Practical Handbook of Seawater Analysis. Fisheries Research Board Canada, 167: $1-310$.

Thayer, G.W. - 1970. Comparison of two storage methods for the analysis of nitrogen and phosphorous fractions in estuarine water. Chesapeake Sci., 11: 155-158.

Valderrama, J.C. - 1995. Methods of nutrient analysis. In: G.M. Hallegraeff, D.M. Anderson and A.D. Cembella (eds.), Manual of Harmful Marine Microalgae. UNESCO, Paris, 251-268.

Varela, R. and FRONTS Group. - 1991. Datos Oceanográficos Básicos de las Campañas FRONTS 1989, FRONTS 1990 y FRONTS 1991 en el Mar Catalán. Datos Informativos Instituto de Ciencias del Mar, Barcelona, 26: 1-71.

Velásquez, Z. - 1997. Fitoplancton en el mediterráneo noroccidental. Ph.D. thesis, Univ. Politècnica de Catalunya.

Venrick, E.L. and T.L. Hayward. - 1985. Evaluation of some techniques for preserving nutrients in stored seawater samples. California Cooperative Oceanic and Fisheries Investigations Report XXVI: $160-168$.

Winkler, L.W. - 1888. Die Bestimmung des in Wasser gelosten Sauerstoffen. Berichte der Deutschen Chemischen Gesellschaft, 21: 2842-2855.

Whitledge, T.E., S.T. Mallory, C.S. Patton and C.D. Wiritk. - 1981. Automated Analysis in Seawater. Nat. Tech. Inf. Serv. Springfield, Brookhaven Nat. Laboratory, USA.

Yentsch, C.S. and D.W. Menzel. - 1963. A method for the determination of phytoplankton chlorophyll and phaeophytin by fluorescence. Deep-Sea Res., 10: 221-231.

Scient. ed.: X.A. Álvarez-Salgado.

Received March 26, 2010. Accepted October 4, 2010.

Published online March 14, 2011. 
APPENDIX 1. - Cruise name, date, number of stations, oceanographic vessel and instrumentation used of the cruises gathered in the present study. Source: I, PEPS Group, 1986; II, Masó and PEPS Group, 1988; III, Varela and FRONTS Group, 1991; IV, Masó and Varimed Group, 1995

\begin{tabular}{|c|c|c|c|c|c|c|c|c|}
\hline Cruise & Date & $\begin{array}{l}\text { Number } \\
\text { of stations }\end{array}$ & $\begin{array}{l}\text { Oceanographic } \\
\text { Ship }\end{array}$ & CTD & Thermometer & Salinometer & Pressure & Source \\
\hline ep-82 & 11-30 July 1982 & 49 & Garcia del Cid & & reversible & induction & line & I \\
\hline$p-83$ & 30 June-17 July 1983 & 83 & Garcia del Cid & Neil Brown & sensor & sensor & sensor & I \\
\hline Pep-84 & 15-30 May 1984 & 53 & Garcia del Cid & & reversible & induction & line & I \\
\hline Fronts-3-85 & 15-26 March 1985 & 17 & Garcia del Cid & Neil Brown (part) & reversible & induction & line & II \\
\hline Fronts-6-85 & 1-6 June 1985 & 23 & Garcia del Cid & & reversible & induction & line & II \\
\hline Pep-86 & 13-24 June 1986 & 39 & Garcia del Cid & & reversible & induction & line & II \\
\hline Fronts-11-86 & 7-12 November 1986 & 15 & Garcia del Cid & & reversible & induction & line & II \\
\hline Pep-87 & 23-30 May 1987 & 20 & Garcia del Cid & & reversible & induction & line & II \\
\hline onts 89 & 13-22 May 1989 & 28 & Garcia del Cid & Sea-Bird SEB 19 (some) & reversible & induction & line & III \\
\hline Front & 9-21 February 1990 & 30 & Garcia del Cid & Neil Brown Mark-III (part) & reversible & conductivity & line & III \\
\hline Fronts 91 & 10-21 April 1991 & 37 & Garcia del Cid & $\begin{array}{l}\text { Neil Brown Mark-III (part 1) } \\
\text { Seabird SBE } 25 \text { (part 2) }\end{array}$ & sensor & sensor & sensor & III \\
\hline onts 92 & 15 Oct.-4 Nov. 1992 & 27 & Garcia & Seabird SBE 25 & sensor & ser & sensor & IV \\
\hline ( & June 1993 & 60 & Hes & Neil-Brow & & & sensor & IV \\
\hline arimed 93 II & 10-16, 23-29 June 1993 & 21 & Hespe & Neil-Brow & sensor & sensor & sensor & IV \\
\hline Varimed 93 III & 18-22 June 1993 & 41 & Hespé & Neil-Brown Mark V & sen & or & sensor & IV \\
\hline Varimed 95 & 2-14 June 1995 & 32 & Hespérides & Neil-Brown Mark V & sensor & sensor & sensor & M. Estrada \\
\hline Meso 95 & 31 May-23 June 1995 & 176 & Garcia del Cid & Neil-Brown Mark-III & sensor & sensor & sensor & A. Cruzado \\
\hline Fans 1 & 1-11 November 1996 & 53 & Garci & Neil-Brown Mark-III & sensor & sensor & sensor & L. Arin \\
\hline Fans 2 & 4-14 February 1997 & 105 & Garcia & Neil-Brow & & & sensor & L. Arin \\
\hline ans 3 & $7-16 \mathrm{Jul}$ & 110 & Garc & Neil-Bro & (c) & sor & sensor & L. Arin \\
\hline Hivern 99 & 20 Feb.-15 March 1999 & 47 & Garcia & Neil-Brown Mark-III & sensor & sensor & sensor & M. Estrada \\
\hline Hivern 200 & 21 Jan.-11 Feb. 2000 & 50 & Garcia & Neil-Brown Mark-III & sensor & sensor & sensor & M. Estrada \\
\hline Cany & Tarch & 32 & Garci & Neil-Bro & & sensor & sensor & M. Emelianov \\
\hline Cany & 24-31 May 2001 & 44 & Garcia del Cid & Neil-Brown Mark-III & sensor & sensor & sensor & M. Emelianov \\
\hline Canyons III & $10-15$ July 2001 & 24 & Garcia del Cid & Sea-bird SBE 25 / Idronaut & sensor & sensor & sensor & M. Emelianov \\
\hline Canyons IV & 26-29 November 2001 & 14 & Garcia del Cid & Neil Brown Mark-III & sensor & sensor & sensor & M. Emelianov \\
\hline Caco 1 & & 67 & Garcia del Cid & Neil Brown Mark-III 1138 & sensor & sensor & sensor & J. Salat \\
\hline Caco 2 & $11-20$ September 2003 & 65 & Garcia del Cid & Neil Brown Mark-III 1138 & sensor & sensor & sensor & J. Salat \\
\hline
\end{tabular}

APPENDIX 2. - Nutrient analysis characteristics for the data gathered from cruises in the NW Mediterranean Sea. Methodologies: S \& P 72, Strickland and Parsons, 1972; W 81, Whitledge et al., 1981; C 89, Cruzado, 1989; G 83, Grasshoff et al., 1983; B+L 99, Bran+Luebbe, 1999; LNSW, low nutrient seawater; DW, distilled water; ASW, artificial seawater, usually 37 - $38 \mathrm{~g} \mathrm{l}^{-1}$ sodium chloride. I to IV, same as Table 1 .

\begin{tabular}{|c|c|c|c|c|c|c|}
\hline Cruise & Autoanalyzer & Methodology & Base line & Preservation & Analyst & Source \\
\hline Pep-82 & Technicon & S \& P, 72 & LNSW, DW & no & 1 & I \\
\hline Pep-83 & Technicon & $S \& P, 72$ & LNSW, DW & no & 1 & I \\
\hline Pep-84 & Technicon & $S \& P, 72$ & LNSW, DW & no & 1 & I \\
\hline Fronts-3-85 & Technicon & S \& P, 72 & LNSW, DW & no & 1 & II \\
\hline Fronts-6-85 & Technicon & $S \& P, 72$ & LNSW, DW & freezing & 1 & II \\
\hline Pep-86 & Technicon & $\mathrm{W}, 81$ & LNSW & no & 2 & II \\
\hline Fronts 11-86 & Technicon & W, 81 & LNSW, DW & freezing & 1 & II \\
\hline Pep-87 & Technicon & W, 81 & $?$ & no & $?$ & II \\
\hline Fronts 89 & Skalar & W, 81; C, 89 & LNSW & no & 2 & III \\
\hline Fronts 90 & Skalar & W, 81; C, 89 & LNSW & no & 2 & III \\
\hline Fronts 91 & Skalar & W, $81 ; C, 89$ & LNSW & no & 2 & III \\
\hline Fronts 92 & Skalar & $\mathrm{W}, 81 ; \mathrm{C}, 89$ & LNSW & no & 2 & IV \\
\hline Varimed 93 I & Skalar & W, $81 ; C, 89$ & LNSW & no & 2,3 & IV \\
\hline Varimed 93 II & Skalar & W, $81 ; C, 89$ & LNSW & no & 2,3 & IV \\
\hline Varimed 93 III & Skalar & $\mathrm{W}, 81 ; \mathrm{C}, 89$ & LNSW & no & 2,3 & IV \\
\hline Varimed 95 & Skalar & W, 81; C, 89 & LNSW & no & 2 & M. Estrada \\
\hline Meso 95 & Technicon & W, 81; C, 89 & LNSW & no & 4 & A. Cruzado \\
\hline Fans 1 & Skalar & W, $81 ; C, 89$ & LNSW & no & 4 & L. Arin \\
\hline Fans 2 & Skalar & W, 81; C, 89 & LNSW & no & 4 & L. Arin \\
\hline Fans 3 & Skalar & W, 81; C, 89 & LNSW & no & 4 & L. Arin \\
\hline Hivern 99 & Evolution-II, Alliance & $\mathrm{G}, 83$ & ASW & freezing & 5,6 & M. Estrada \\
\hline Hivern 2000 & Evolution-II, Alliance & $\mathrm{G}, 83$ & ASW & freezing & 5 & M. Estrada \\
\hline Canyons I & Evolution-II, Alliance & $\mathrm{G}, 83$ & ASW & freezing & 7 & M. Segura \\
\hline Canyons II & AA3, Bran + Luebbe & $\mathrm{B}+\mathrm{L}, 99$ & ASW & freezing & 7 & M. Segura \\
\hline Canyons III & AA3, Bran + Luebbe & $\mathrm{B}+\mathrm{L}, 99$ & ASW & freezing & 7 & M. Segura \\
\hline Canyons IV & AA3, Bran + Luebbe & $\mathrm{B}+\mathrm{L}, 99$ & ASW & freezing & 7 & M. Segura \\
\hline Caco 1 & AA3, Bran + Luebbe & $\mathrm{B}+\mathrm{L}, 99$ & ASW & freezing & 7 & M. Segura \\
\hline Caco 2 & AA3, Bran + Luebbe & $\mathrm{B}+\mathrm{L}, 99$ & ASW & freezing & 7 & M. Segura \\
\hline
\end{tabular}

